An ESRC Research Group

\title{
The Dynamics of Returns to Education in Kenyan and Tanzanian Manufacturing
}

\section{GPRG-WPS-017}

\author{
Måns Söderbom, Francis Teal, Anthony Wambugu And Godius \\ Kahyarara
}

\section{Global Poverty Research Group}

Website: http://www.gprg.org/

The support of the Economic and Social Research Council (ESRC) is gratefully acknowledged. The work was part of the programme of the ESRC Global Poverty Research Group. 


\title{
The Dynamics of Returns to Education in Kenyan and Tanzanian Manufacturing*
}

\author{
Måns Söderbom ${ }^{(1)}$, Francis Teal ${ }^{(1)}$, Anthony Wambugu ${ }^{(2)}$ and Godius Kahyarara ${ }^{(1),(3)}$
}

April 2005

\begin{abstract}
We use micro data on manufacturing employees in Kenya and Tanzania to estimate returns to education and investigate the shape of the earnings function in the period 1993-2001. In Kenya, there have been long run falls in the returns to education while for Tanzania there is evidence of rising returns in the 1990s. The earnings functions are convex for both countries and this result is robust to endogeneity. Convexity may be part of the explanation as to how rapid expansion of education in Africa has generated so little growth if expansion has been concentrated at lower levels of education.
\end{abstract}

Keywords: Returns to education, Africa, Kenya, Tanzania, manufacturing.

Word count: 8,873 .

\footnotetext{
* We are grateful to Jonathan Temple (Editor), two anonymous referees, Marcel Fafchamps, Geeta Kingdon, Jim Malcomson, Janvier Nkurunziza, Margaret Stevens and participants at a CSAE lunchtime seminar and a Labour Economics seminar at the Department of Economics, Oxford, for several constructive comments on earlier versions of the paper. All errors are our own. Correspondence to Söderbom at Mans.Soderbom@economics.oxford.ac.uk

${ }^{(1)}$ Centre for the Study of African Economies, Department of Economics, University of Oxford, UK

(2) Department of Economics, Kenyatta University, Nariobi, Kenya.

${ }^{(3)}$ Economic and Social Research Foundation, Dar es Salaam, Tanzania.
} 


\section{Introduction}

Returns to education remain of central policy concern in both developed and developing countries. In developed countries observed rises in returns to education have been imputed to skill biased technical change (Katz and Autor, 1999). In poorer countries such as those of Sub-Saharan Africa (SSA) it has been argued that returns may have been falling as a result of rapid expansion of education. As educational supply grows without a commensurate rise in demand, the probability of getting a job for any given level of education declines and, among those with jobs, returns may fall. ${ }^{1}$ The limited evidence of how wages have changed in Africa in the recent past suggests they have fallen, possibly substantially. Squire and SuthiwartNarueput (1997) document that real minimum wages halved in Kenya between 1970 and 1985, and fell even more in Ghana and Zaire. However it is known that in many countries minimum wages are not enforced and the numbers are uninformative as to how the returns to education have been affected.

Policy interest focuses not only on the average return to education but on the dispersion of returns across education levels. A prominent feature of policy towards education in SSA has been the priority given to expanding primary education (e.g. World Bank, 1995). Such an emphasis is seen as being justified, in part, by the finding that returns to education are highest at lower levels (Psacharopoulos, 1994; Psacharopoulos and Patrinos, 2001). The shape of the earnings function is a key factor for understanding how policies of education expansion will impact on incomes. If innovations in educational policy impact primarily on those with high education costs, and the earnings function is concave, then returns to such reforms will be relatively high. However, the view that the earnings function is concave in education has

\footnotetext{
${ }^{1}$ Bennell has recently argued as follows: "During the 1960s and 1970s, obtaining a 'good' job in the rapidly expanding formal sector of the economy provided a powerful incentive for households to invest in primary education (especially for boys). During the last 20 years, however, wage employment opportunities have contracted sharply in many countries as have formal sector incomes especially in the public sector", Bennell (2002, p.1186). An influential argument that educational expansion will be self-defeating in that it will simply result in higher qualifications being needed for any given job can be found in Dore (1976). The implications of his argument for Kenya and Tanzania in the 1990s can be found in Toyoda (1997) and Cooksey and Riedmiller (1997).
} 
recently been challenged for both developed and developing countries. ${ }^{2}$ If in fact the earnings function is convex, so that the marginal returns to education are lowest for the individuals with the least education, giving priority to investment in primary education may have little impact on poverty unless the individuals affected by the reforms proceed to higher levels of education. $^{3}$

For poor developing countries, such as those in SSA, evidence is very limited as to what the earnings function looks like (its shape) and how the returns to education have changed over time. ${ }^{4}$ This paper considers these issues using comparable repeated crosssection data on workers in manufacturing firms in Kenya and Tanzania over the 1990s. We also put the results in a longer term context as excellent data exist for the returns to education in Kenya and Tanzania in 1980 (Knight and Sabot, 1990). We thus fill a significant information gap. Further, the different educational policies pursued by Kenya and Tanzania in the period since independence have been argued to constitute close to a natural experiment (Knight and Sabot, 1990). In the 1980s, while Kenya allowed a rapid expansion of secondary education, much of it privately financed, Tanzania severely restricted access to secondary education and introduced wage polices to reduce differentials. In the 1990s educational and other policies in Tanzania became much more similar to those in Kenya. A comparative analysis of these two countries over this period will therefore shed light on some of the

\footnotetext{
${ }^{2}$ In a series of papers Bennell (1996a,b; 2002) has argued that the pattern of the returns to education do not follow that asserted by Psacharopoulos (1994). Bennell's underlying arguments are consistent with the shape being convex. Direct evidence of convexity in some parts of the domain of the earnings function is provided by Belzil and Hansen (2002) for the U.S. and by Kingdon and Unni (2001) and Duraisamy (2002) for India.

${ }^{3}$ Throughout the paper we consider the Mincerian returns to education which do not reflect the private costs, other than foregone wages, or the possible non-wage benefits. It may be that the social returns to primary education are high e.g. in terms of health, but we are unable to investigate this with our data. Further, because primary schooling is a necessary input into postprimary, the prospect of postprimary schooling may raise the primary return above the rate as conventionally measured (Appleton, Hoddinott and Knight, 1996).

${ }^{4}$ Much of the available evidence is limited to relatively short periods of time. Krishnan, Sellassie and Dercon (1998) show that educational returns did not change in urban Ethiopia despite labour market reforms instituted in early 1990s. In contrast in Uganda, from 1992 to 1999, returns to education increased markedly, Appleton (2002) and in Ghana from 1987 to 1991 there is evidence of rising returns, Canagarajah and Thomas (1997). Where longer run comparisons have been made there is evidence of falls. In South Africa, Moll (1996) reports that returns to primary education declined from 1960 to 1975. In urban labour markets in Kenya between 1978 and 1995 Appleton, Bigsten and Manda, (1999) report declines in returns to education for workers with secondary education and below.
} 
general connections between education policy, education and earnings (e.g. whether the returns to education change when policies change, and if so, how quickly).

The rest of the paper is organised as follows: Section 2 outlines our empirical framework; Section 3 discusses the data and shows summary statistics; Section 4 shows OLS estimates of the earnings functions, and provides a comparative analysis over time and across age groups; Section 5 shows additional results in which education is treated as an endogenous variable; and Section 6 provides conclusions.

\section{The Earnings Model}

Our data begin in 1993 and span seven years for Kenya and eight years for Tanzania. Our main use of these data is to estimate the earnings-education profile, and to investigate if there is any evidence of changes in the profile over time or differences across age groups at given points in time. We write our baseline model of earnings as

$$
\ln w_{i}=\boldsymbol{\alpha}_{\mathbf{a t}} \mathbf{x}_{\mathbf{i}}+f_{a t}\left(s_{i}\right)+v_{i}
$$

where $w_{i}$ is real earnings of individual $i, \mathbf{x}_{\mathbf{i}}$ is a vector of worker characteristics excluding education, $\boldsymbol{\alpha}_{\mathrm{at}}$ is a parameter vector, $s_{i}$ is the years of education, $f_{a t}($.$) is the earnings-$ education profile, $v_{i}$ is a residual, and $a$ and $t$ denote age group and time, respectively. Variables included in $\mathbf{x}_{\mathbf{i}}$ are years of tenure, age and age squared, a dummy variable for whether the individual is a male or not and a dummy variable for whether the individual lives in the capital city. It is likely that an important effect of education is to enable individuals to get high-wage jobs (e.g. managerial positions), or to get into certain high-wage sectors or firms. Our primary objective in this paper is to estimate the total returns to education, which may partly reflect such selection effects. We therefore do not include in $\mathbf{x}_{\mathbf{i}}$ variables that may be channels through which education affects earnings, e.g. occupation, firm size and sector. ${ }^{5}$

\footnotetext{
${ }^{5}$ See Fafchamps, Benhassine and Söderbom (2004), for an analysis of how much of the total returns to education in eleven African countries is due to sorting across firms and sorting across occupations within firms. See Söderbom, Teal and Wambugu (2005) for an investigation of the relationship between earnings and firm size in Ghana and Kenya.
} 
Key for our purposes is the estimation of the earnings-education profile $f_{a t}(\cdot)$. We adopt a semiparametric approach modelling $f_{a t}(\cdot)$ as a piecewise linear spline function with $J$ nodes at selected levels of education:

$$
f_{a t}\left(s_{i}\right)=\mu_{t}+\imath_{a}+\beta_{0 a t} \cdot s_{i}+\sum_{j=1}^{J} \beta_{j a t} \cdot \max \left\{s_{i}-\theta_{j}, 0\right\},
$$

where $\theta_{j}$ denotes the position of the $j$ th node, and $\mu_{t}$ and $l_{a}$ are time and age group effects (intercept shifters). Importantly this approach, which is quite flexible, allows for a non-linear relationship between education and earnings. The coefficient $\beta_{0 a t}$ is interpretable as the slope of the profile in the first education interval (i.e. for the lowest levels of education), while $\beta_{\text {jat }}$ for $j=1,2, \ldots, J$ is interpretable as the change in the slope of the profile that results from moving from the education interval $\left\{\theta_{j-1}, \theta_{j}\right\}$ to $\left\{\theta_{j}, \theta_{j+1}\right\}$, where $\theta_{0}=0$. The slope of the earnings function in the interval $\left\{\theta_{j-1}, \theta_{j}\right\}, j=1,2, \ldots, J$, is thus given by $\beta_{0 a t}+\sum_{m=1}^{j} \beta_{m a t}$. Hence, if $\beta_{1 c t}=\beta_{2 c t}=, \ldots,=\beta_{J c t}=0$, the earnings function is linear. Throughout the analysis we put in nodes of the earnings-education profile $f_{a t}($.$) at 7, 10$ and 12 years of education. With four segments in the profile there is a reasonable number of observations in each category. We divide the data into two age groups only, where an individual is considered 'young' if his/her age is less than 30 years and 'old' otherwise.

It is widely recognised that using OLS to estimate the returns to education from crosssection data is potentially problematic. The standard concern in the literature is that education is an endogenous variable, positively correlated with the earnings residual due to unobserved ability. ${ }^{6}$ It is also possible that there is heterogeneity in the returns to education at given levels of education, and that unobserved ability is correlated with the returns (see e.g. Belzil, 2004). In either case, OLS estimates of the parameters would be biased. We allow for both forms of endogeneity in Section 5, using a control function approach.

\footnotetext{
${ }^{6}$ However, the common finding in the empirical literature is that estimated returns rise as a result of treating education as an endogenous variable. We return to this point below.
} 


\section{Data}

We use survey data on employees in the manufacturing sectors in Kenya and Tanzania. ${ }^{7}$ For both countries we have four years of data: the Kenyan data cover 1993-1995 and 2000; the Tanzanian data cover 1993, 1994, 1999 and $2001 .^{8}$ Four broadly defined manufacturing subsectors were surveyed: food processing, textiles and garments, wood and furniture, and metalworking including machinery. These sub-sectors comprise the bulk of manufacturing employment in both countries. Large as well as small firms, including informal ones, were included in the sample, and each wave of the data contains information on 150-220 firms. In each firm up to 10 workers were interviewed to provide information on personal characteristics, characteristics of their jobs and information on earnings and allowances. The aim was to sample employees representing all types of jobs in the firms, e.g. casual workers, production workers, supervisors, office clerks and managers. There is a panel dimension at the firm level, but not at the individual level. ${ }^{9}$

Table 1 shows summary statistics of the key variables in the analysis. To facilitate comparison across the two countries, earnings are recorded on a monthly basis and expressed in constant 1993 US Dollars. The average monthly earnings is USD 75 in Kenya and USD 55

\footnotetext{
${ }^{7}$ There are advantages and disadvantages to focussing solely on individuals in the manufacturing sector and not the whole population. Because of significant private ownership the manufacturing sector provides a good basis for interpreting returns to education as returns to productive skills. In the public sector earnings are determined by a number of factors orthogonal to productive ability, and so the returns to education would have a different interpretation in this sector. Further, focusing on one sector only ensures that changes over time are not driven by changes in the relative sizes of different sectors, across which there may be technological differences. A related point is that, for both Tanzania and Kenya, there is no evidence of significant technological progress over the 1990s (Bigsten, 2002; Pack, 2002). We would therefore argue that for our sample technology is constant. A possible disadvantage of focussing only on the manufacturing sector is that the results may be biased by sample selectivity. We discuss this in Section 5 .

${ }^{8}$ The first three waves of the Kenyan data, and the first two waves of the Tanzanian data, were collected as part of the World Bank's Regional Program on Enterprise Development (RPED), while the remaining waves of the data were collected by teams from the Centre for the Study of African Economies, University of Oxford. The survey instruments and the sampling design were very similar both over time and across the two countries, thus providing an excellent basis for comparative analysis. For general information on the surveys, see Söderbom (2001) and Bigsten and Kimuyu (eds.) (2002) for Kenya; and Harding, Kaharaya and Rankin (2002), Harding, Söderbom and Teal (2002), for Tanzania.

${ }^{9}$ See Bigsten et al. (2000) for a study of the returns to physical and human capital in five African countries. For a panel data analysis based on the firm level data, see Söderbom and Teal (2004).
} 
in Tanzania. The average years of education is 9.1 in Kenya and 8.8 in Tanzania, thus the large earnings differential across the two countries is not matched by a similarly large differential in years of education. Figures 1 and 2 illustrate the sample distributions of earnings (in natural logarithms) and education, distinguishing the two age groups. There is considerable sample variation in both variables. While there is an obvious differential across the countries in average earnings, the distributions have similar shapes. For education, however, the sample distributions differ markedly across the countries. In Tanzania, there is a spike in the data at 7 years of education, while in the Kenyan sample the distribution features less kurtosis. This pattern of similar earnings distributions and different education distributions is interesting. If the aggregate supply of education impacts on the returns to education, and the differences in supply are not mirrored by differences in aggregate demand for educated workers, we would expect the earnings-education profiles to differ significantly across the countries. We now turn to regression analysis to investigate the returns to education in detail.

\section{Earnings Function Estimates}

In this section we report OLS estimates of the earnings function parameters, assuming education to be exogenous. All the parameters are treated as fixed coefficients. If at a given level of education there is variation in the returns across individuals independent of education, the estimates are interpretable as averages of individual returns. We allow for endogenous education and for correlation between education and individual returns in Section 5. We estimate the earnings equation separately for each age group and time period. We show results for the two countries in Tables 2 and 3, and to facilitate interpretation we show the predicted earnings-education profiles in Figures 3a-b. Three main results emerge.

First, for both countries there is strong evidence that earnings are non-linear in education. For 15 of the 16 regressions reported in Tables 2-3 we can reject linearity, and by implication constant marginal returns to education, at the 10 per cent level of significance or lower. Most of the coefficients on the $\max ($.$) terms are positive, suggesting that earnings are$ 
convex in education. Many of the coefficients on $\max (0, \mathrm{EDUC}-12)$ are relatively large, indicating sharp increases in the marginal returns to education after 12 years of education. This is also apparent in the graphs. Indeed, in Tanzania the main reason why earnings are non-linear in education is that returns are high at high levels of education, and in six out of eight cases we can accept at the ten per cent level of significance the hypothesis that the earnings-education profile is linear between 0 and 12 years of education. In contrast, for Kenya there is evidence of non-linearities in the earnings profile at lower levels of education, and at the five per cent level we can reject in five cases out of eight the hypothesis that the earnings-education profile is linear between 0 and 12 years of education.

Second, for both countries we observe changes in the earnings profiles over time. In Kenya there is a clear upward intercept shift referring to 1995, which was sustained in 2000 for the old age group but not for the young. The shape of the Kenyan profile, however, looks quite stable over time, except possibly for 1994. In Tanzania the earnings profiles of 1994, 1999 and 2001 exhibit more pronounced non-linearities than those of 1993. Comparing the last time period to the first, it appears earnings have become more convex over time for both age groups.

Third, the data suggest that for both countries earnings profiles differ across the two age groups. In the range $(0,12)$ years of education the profiles are typically steeper for the old than for the young age group, especially for Tanzania. In the case of Tanzania it also looks as though the earnings profile is less convex for the old age group than for the young. In both countries the returns to education for the young age group are typically quite low before the tertiary level. We test formally for age group differences and time differences in the earningseducation relationship below.

In addition to these three results we also note the following: earnings, conditional on the human capital variables, are higher in Kenya than in Tanzania (this is apparent from the graphs); the earnings-age profile is, in most cases, inverse u-shaped (of course, these are within age group profiles); the tenure coefficient is small, typically smaller than 0.01 and insignificant; the male coefficient is usually positive but only significant at the five per cent 
level in two out of the 16 regressions; and there is a wage premium to working in the capital city. We can always reject the hypothesis that the earnings-education profile is flat, and except for the young age group in Tanzania in 1994 and 1999 we can also reject at the five per cent level the hypothesis that the earnings-education profile is flat between 0 and 12 years of education. Thus, returns are certainly low at low levels of education, but in most cases they are significantly different from zero.

We now analyse in more detail how returns to education have changed over time and how these returns differ across the two countries and the two age groups. Much of the comparative work on the returns to education across countries uses a linear specification of the earnings function (e.g. Trostel et al. 2002), implying that the average equals the marginal return to education. In our data linearity can typically be firmly rejected, thus marginal returns will differ from the average. We summarise in Table 4 the marginal returns to education for 1993 and 2000/01 for both countries, distinguishing the old and young age groups. We show averages of the individual marginal effects for the whole samples as well as a breakdown by educational level. ${ }^{10}$ We do the latter by calculating average marginal returns within the following categories: $E_{2} 1-4$ years; $E_{3}$ 5-7 years; $E_{4} 8-11$ years; and $E_{5} 12+$ years. In Table 5 we use this breakdown to show how the predicted earnings differentials in 1993 and 2000/01 compare to 1980, drawing on the study by Knight and Sabot (1990). ${ }^{11}$

First consider the averages of the marginal returns across all education levels combined. ${ }^{12}$ Throughout, these are higher in 2000/01 than in 1993. In column [5] we report $p$ values associated with tests of the hypothesis that there is no difference in the average marginal returns over time (for both age groups). In Kenya there is no evidence of significant

10 The estimation of the marginal effects is based on the two-sided formula $f_{a t}^{\prime}\left(s_{i t}\right)=\left(f_{a t}\left(s_{i t}+\varepsilon\right)-f_{a t}\left(s_{i t}-\varepsilon\right)\right) / 2 \varepsilon$, where $\varepsilon=0.5$ (i.e. half a year). For observations between node $j$ and $j-1, j>0$, this is equal to $\beta_{0 a t}+\sum_{m=1}^{j} \beta_{\text {mat }}$; for observations at node $j$ this is the average of the slopes immediately to the right and left of the node, i.e. $\beta_{0 a t}+\sum_{m=1}^{j} \beta_{m a t}+0.5 \beta_{j+1, a t}$.

${ }^{11}$ When Knight and Sabot did their survey $E_{2}$ and $E_{3}$ corresponded to primary education (standards 1-4 and 5-7, respectively), $E_{4}$ to secondary, and $E_{5}$ to tertiary education. In 1985 Kenya reformed its education system to 8 years for primary education, 4 years for secondary, and 4 years for university.

${ }^{12}$ These results are similar to those obtained from linear specifications (not reported). 
differences over the two time periods considered here. In Tanzania average marginal returns rose from 6 per cent in 1993 to 9 per cent in 2001 for the young, and from 8 to 13 per cent for the old, and we can reject constant averages at the five per cent level. For both countries, average returns are always higher in the old age group, but we can accept the null hypothesis that the averages are the same in the two age groups (column 6).

The breakdown of the marginal returns by education level confirms the magnitude of the convexity in the returns to education already apparent from Figures 3a-b. For both countries and both age groups, the marginal return on post-secondary education is higher, in most cases substantially higher, than the returns before the secondary level. In both countries and for both age groups the average marginal return on education for those with postsecondary exceeded 27 per cent in $2000 / 01$. There is evidence of a large and statistically significant increase in the return to post-secondary education in Tanzania between 1993 and 2001. Thus, the main reason for the increase in the average return in Tanzania documented above is that the earnings function has become significantly more convex.

Next, we look in detail at total wage differentials associated with various levels of education over a fixed baseline level. As we are using the same classification of education variables as that adopted by Knight and Sabot (1990), we can also compare the 1990s with 1980. ${ }^{13}$ Table 5 shows predicted total earnings premiums (in logarithmic form) attributable to education, using two different baselines: no education (panel $A$ ) and $E_{3}$ (5-7 years of education) (panel B). In Kenya, there is evidence of differences in the wage differentials across age groups at relatively high levels of education. On balance, earnings differentials attributable to education are larger in the old age group than in the young. When the baseline

\footnotetext{
${ }^{13}$ The sample of workers in Knight and Sabot (1990) was drawn from the wage labour forces in Nairobi and Dar es Salaam. Forty-nine per cent of the sampled individuals in Kenya were manufacturing workers, 58 per cent in Tanzania (see Table A-5 in Knight and Sabot). It is possible that the earnings-education profile differs between manufacturing and non-manufacturing wage employees, in which case the long term comparisons reported in Tables 4 and 5 may partly reflect differences in sector compositions in the samples. We do not have any data that would enable us to assess if this is a problem or not.
} 
is $E_{3}$ (Panel $B$ ), there is strong evidence of such age group differentials. ${ }^{14}$ By year 2000, postsecondary education is associated with an earnings differentials of $1.08 \log$ points (which corresponds to a differential in levels of 194 per cent) for an individual in the old age group, and 0.76 (114 per cent) for an individual in the young age group. There is no evidence of differences between 1993 and 2000 at any of the levels considered here, but there is a uniform pattern of wage differentials being smaller in 2000 than in 1980 suggesting that returns in Kenya have indeed fallen over this period.

In Tanzania we observe in most cases increases in the wage differentials between 1993 and 2001, and with $E_{3}$ as the baseline we can reject at the five per cent level of significance the hypothesis that wage differentials associated with post-secondary education are constant over time. There is also evidence of age group differences amongst individuals with postsecondary education, with lower differentials amongst the young. Comparing over the longer term, in all cases except $\mathrm{E}_{2}$ (1-4 years) in Panel A, the Tanzanian wage differentials for 1980 are bracketed by that for the old and the young, suggesting that the shape of the earnings function of 2001 is not dissimilar to the shape of 1980.

We now investigate whether our findings are sensitive to functional form. Our spline function is flexible but linearity within each segment is imposed, which may be restrictive. Further, exactly where the earnings profile has kinks is determined by our own "eye-balling" of the data. These are potential weaknesses. We now consider the effects of modelling the earnings-education profile as a third-order polynomial (i.e. a cubic), which sidesteps these particular problems. To conserve space we do not report the results from these regressions (they are available on request). Instead we show in Figures 4a-b the estimated earnings profiles. The shapes of these profiles are similar to their spline function counterparts and there is clear evidence of convexity. The squared and cubed education effects are jointly significant at the five per cent level or better in all cases except for the young age group in Kenya in year 2 (tests not reported). We have also investigated how the main findings are affected by

\footnotetext{
${ }^{14}$ Recall from Figure 2 that relatively few workers in the sample have less than 7-8 years of education, and so arguably the estimates in Panel B provide a better reflection of the main trends in the data than
} 
including sector controls in the regressions (recall that our data contain individuals working in four manufacturing sub-sectors in the two countries). The results, which are not reported in order to conserve space, indicate that there are significant wage differences across sectors in both countries but the estimated earnings profiles do not change much as a result of including the sector controls. In particular, the general pattern of convexity of the earnings functions holds within, as well as between, sectors. These results are available on request from the authors.

\section{Endogenous Education}

As is well-known, the OLS estimator will give biased estimates of the returns to education if education is 'endogenous', i.e. correlated with the residual in the earnings equation. A common concern in the literature is that education may be positively correlated with unobserved labour market ability, and that the estimates of the returns to education would be upward biased as a result. ${ }^{15}$ For our purposes we are concerned not simply with whether the average returns to education are biased up, but whether our finding of convexity is also due to our failure to allow for such endogeneity. Further, our data set consists of employees in the manufacturing sector, and so self-selection based on unobserved factors into the sector may give rise to selection bias. In this section we report additional results that should be more robust to these potential problems than the OLS estimates.

In order to be explicit about the role of unobserved ability, we re-write the earnings function as

$$
\ln w_{i}=\boldsymbol{\alpha}_{\mathbf{a t}} \mathbf{x}_{\mathbf{i}}+f_{a t}\left(s_{i}\left(\lambda_{i}\right) ; \lambda_{i}\right)+\eta\left(\lambda_{i}\right)+v_{i},
$$

where $\lambda_{i}$ is a zero-mean variable denoting unobserved ability, $\eta(\cdot)$ is a continuous function, $v_{i}$ is a residual orthogonal to all random terms on the right hand side of $\left(1^{\prime}\right)$, and the rest of

\footnotetext{
those in Panel A.

${ }^{15}$ Belzil and Hansen (2002) find a strong positive correlation between unobserved market ability and unobserved taste for schooling, thus leading to substantial upward bias in the OLS estimates of the
} 
the notation is as in Section 2. Unobserved ability is thus potentially correlated with both schooling and the earnings-education profile. Suppose, in reduced form, schooling is given by

$$
s_{i}=\psi \cdot z_{i}+\lambda_{i},
$$

where $z_{i}$ is a vector of variables (instruments) that are independent of $\lambda_{i}$ and uncorrelated with $v_{i}$. Suppose further that, in the spline function $f$, we have

$$
\boldsymbol{\beta}_{\text {at }}\left(\lambda_{i}\right)=\left[\beta_{0 a t}\left(\lambda_{i}\right) \beta_{1 a t} \beta_{2 a t} \beta_{3 a t}\right],
$$

i.e. unobserved ability affects the slopes of the different segments of the earnings-education profile but not the differences in the slopes between segments. The parameter $\beta_{0 a t}$ is thus now explicitly a random coefficient. ${ }^{16}$ For simplicity, let

$$
\beta_{0 a t}\left(\lambda_{i}\right)=\bar{\beta}_{0 a t}+\delta\left(\lambda_{i}\right),
$$

where $\bar{\beta}_{0 a t}$ is a constant and $\delta$ a continuous function with $\delta(0)=0$ for notational convenience

The conventional form of ability bias arises in this framework when $\eta(\cdot)$ is linear and increasing in $\lambda_{i}$, and $\lambda_{i}$ does not affect $\beta_{a t}(\delta=0) .{ }^{17}$ For purposes of exposition, abstract from time and age group effects and assume the earnings equation is linear in education (i.e. $\left.\beta_{1}=\beta_{2}=\beta_{3}=0\right):$

$$
\ln w_{i}=\boldsymbol{\alpha} \mathbf{x}_{\mathbf{i}}+\bar{\beta}_{0} \cdot s_{i}\left(\lambda_{i}\right)+\eta_{1} \lambda_{i}+v_{i} .
$$

With $\eta_{1}>0$ and $\lambda_{i}$ unobserved, OLS estimates of the return to education will be upward biased. Further, if the return to education is random and correlated with unobserved ability (i.e. $\delta$ is not constant), i.e.

$$
\ln w_{i}=\boldsymbol{\alpha} \mathbf{x}_{\mathbf{i}}+\left(\bar{\beta}_{0}+\delta\left(\lambda_{i}\right)\right) \cdot s_{i}\left(\lambda_{i}\right)+\eta_{1} \lambda_{i}+v_{i},
$$

returns to schooling. A more common finding in the empirical literature, however, is that estimated returns rise as a result of treating education as an endogenous variable, see e.g. Card (2001).

${ }^{16} \mathrm{It}$ is straightforward to generalize the model and allow $\beta_{1 a t}, \beta_{2 a t}, \beta_{3 a t}$ to be correlated with $\lambda_{i}$. Doing this with our data generally results in imprecise estimates (sometimes very imprecise). We attribute this to the small sample size.

${ }^{17}$ See for instance eq. (7) in Card (2001) under $b_{i}=\bar{b}$ and $k_{1}=0$ (using Card's notation). 
then this will result in a non-linear association between education and earnings in the data which is not causal. Notice that if $\eta_{1}>0$ and $\delta$ is increasing in $\lambda_{i}$, i.e. individuals who tend to get a lot of education tend to have high earnings conditional on education and high returns to education, then failure to control for this unobserved factor in the estimation will result in a convex earnings-education profile even though the true functional form is linear.

To allow for a flexible non-linear earnings-education profile whilst controlling for effects of unobserved ability on earnings and returns to earnings, we adopt a two-stage control function approach. ${ }^{18}$ In the first stage we run a regression of the form in (2), thus regressing education on a set of instruments. Based on this regression we estimate the residual, denoted $\hat{\lambda}_{i}$. In the second stage we estimate an earnings function in which $\hat{\lambda}_{i}$ is used as a 'control variable' for ability. Provided standard conditions for identification hold, and provided the instruments $z_{i}$ are independent of $\lambda_{i}$ and uncorrelated with $v_{i}$, this procedure will give consistent estimates of the parameters of interest. ${ }^{19}$ As discussed by Card (2001), the control function approach is more robust than 2SLS when slope parameters potentially co-vary with the unobserved factors of the model. Further, even if all slope parameters are constant, 2SLS is likely to result in relative imprecise parameter estimates since the model is non-linear in the endogenous variable. ${ }^{20}$ These are the two reasons we prefer this estimator over 2SLS. As is well known, in the special case where the model is of the form in (4), 2SLS and the control function estimator are equivalent.

\footnotetext{
${ }^{18}$ For a recent discussion of the control function approach in the context of estimating semiparametric models, see Blundell and Powell (2001). Wooldridge (2002a) considers the control function for estimation of parametric non-linear models (probits and tobits). For an early application of the control function approach in the context of estimating earnings functions, see Garen (1984).

${ }^{19}$ Zero covariance between $z_{i}$ and $\lambda_{i}$ is generally not sufficient for consistency since the model is non-linear in the endogenous explanatory variable, see Blundell and Powell (2001).

${ }^{20}$ To apply 2 SLS to our model we would have to estimate four first stage regressions, modelling each component of the spline function separately, and then use the predictions instead of the actual values in the second stage. A much richer instrument set would thus be required for 2SLS than for the control function estimator. Unlike the control function approach, however, 2SLS does not require independence between the instruments and the unobserved component of the earnings equation - just zero covariance. Thus, $2 \mathrm{SLS}$ is less restrictive than the control function, but identification is likely to be harder to achieve in practice. Essentially, what the independence assumption buys us is that we only need to add a univariate function in the first stage, rather than instrumenting for four variables.
} 
We require valid exclusion restrictions, i.e. variables that are correlated with education and uncorrelated with the earnings residual. In the last wave of the data there is information on the distance to primary school at the age of six and to secondary school at the age of twelve, as well as on parents' education and main occupations. These are our potential instruments for education. Distance to school is a supply side measure of education and it could therefore be reasonably argued that this variable is correlated with education and not with ability (Card, 2001). Several recent studies, mostly based on U.S. data, have used similar information to form instruments for education. Family background variables have been used as instruments for education in many previous studies, primarily on the grounds that such variables should have no causal effect on earnings. ${ }^{21}$

In our discussion so far, we have considered a relatively conventional role of unobserved ability in potentially leading to bias. In Kenya and Tanzania, unlike more developed economies, having a job in the wage sector is atypical of outcomes in the labour market. Such sample selection may lead to bias in the OLS estimates and thus in our comparison of returns over time. Since we do not have data on individuals outside the manufacturing sector, we are limited in our ability to control for endogenous sample selection. In particular, we are unable to use a sample selection model along the lines proposed by Heckman $(1976,1979)$, since we cannot estimate a participation equation. Can the control function address the sample selectivity problem? The answer is yes, provided the instruments are independent of the error term in the selected sample. One example of a model in which this will apply is when the job selection model is of the form

$$
I_{i}=\left\{\begin{array}{l}
1 \text { if } \lambda_{\mathrm{i}}+u_{1 i}>0 \\
0 \text { otherwise }
\end{array},\right.
$$

\footnotetext{
${ }^{21}$ While these variables may have no direct causal effect on earnings it is still possible that they are invalid instruments, e.g. if the ability of parents is correlated with that of their children or if parents with a lot of education (or with certain jobs) can help their children develop skills that are subsequently rewarded in the labour market. Similarly, if parents with highly able children may choose to live close to a school, the distance variable will not be a valid instrument. Furthermore, it is possible the supplyside instruments are weak instruments for selection into post-secondary education, which could result in bias (see Hahn and Hausman, 2003, for a recent overview of the problems posed by weak instruments). For these reasons, a dose of caution in interpreting the instrumental variable results is recommended.
} 
where $I_{i}$ is an indicator variable equal to one if the individual has a manufacturing job and zero otherwise and $u_{1 i}$ is an unobserved factor which is potentially correlated with $v_{i}$. Suppose in the population $u_{1 i}$ follows a standard normal distribution and let $v_{i}=\omega \cdot u_{1 i}+u_{2 i}$, where $\omega$ is a parameter and $u_{2 i}$ is random term independent of $u_{1 i}, \mathbf{x}_{\mathbf{i}}, z_{i}, \lambda_{i}$. In this case the expected value of $v_{i}$ conditional on selection and ability is given by:

$$
E\left[v_{i} \mid I_{i}=1, \mathbf{x}_{\mathbf{i}}, z_{i}, \lambda_{i}\right]=\omega \sigma_{v} I M\left(\lambda_{i}\right),
$$

where $\operatorname{IM}($.$) is the inverse Mill's ratio (see e.g. Wooldridge, 2002b, p.522). Estimating the$ earnings function using OLS based on the selected sample would thus generate a combination of conventional ability bias and selection bias. Because $\operatorname{IM}($.$) is decreasing in ability, the$ OLS estimates may in fact be downward biased if the selectivity mechanism is sufficiently strong and $\omega>0$, even though education and ability are positively correlated in the population. In contrast, provided the functional form of the control function is flexible enough to approximate $\eta\left(\lambda_{i}\right)+\omega \sigma_{v} I M\left(\lambda_{i}\right)$ well, this approach will be consistent. More general cases of sample selection can be more problematic, however. For instance, if education determines selection then all instruments in $z_{i}$ will generally be correlated with the earnings residual in the selected sample, in which case they will not be valid instruments. This will be the case even if $\omega=0$, since selection depends both on $z_{i}$ and $\lambda_{i}$. Of course, if $\omega=0$ and education is independent of unobserved ability, the earnings equation can be estimated consistently with OLS on the selected sample, even if education determines selection.

\section{Results}

Table 6 reports control function results using the last wave of data for both countries. ${ }^{22} \mathrm{We}$ begin by checking that parental characteristics and distance to school indeed have explanatory power for education, a necessary condition for identification. Based on the first stage regressions, where education is regressed on all exogenous variables, we test for the joint 
significance of the coefficients on parental characteristics and distance to school. For all four specifications, we can safely reject the hypothesis that these coefficients are jointly zero (EXCRES).

Having established this we next consider our most general earnings model, which takes the form

$$
\ln w_{i}=\boldsymbol{\alpha} \mathbf{x}_{\mathbf{i}}+\bar{\beta}_{0} \cdot s_{i}+\delta\left(\hat{\lambda}_{i}\right) \cdot s_{i}+\sum_{j=1}^{3} \beta_{j} \cdot \max \left\{s_{i}-\theta_{j}, 0\right\}+\eta\left(\hat{\lambda}_{i}\right)+v_{i}
$$

and where we approximate $\delta\left(\hat{\lambda}_{i}\right)$ and $\eta\left(\hat{\lambda}_{i}\right)$ by third-order polynomial functions. Based on the results from this specification we test if the coefficients on the cross terms between $\delta\left(\hat{\lambda}_{i}\right)$ and education are significant. Within our modelling framework this is interpretable as a test for whether the returns to education are correlated with unobserved ability. For all four specifications we can accept the hypothesis that there are no such interaction effects (RETHET). We therefore move on to specification without interaction terms, which should give us more efficient estimates (to conserve space, we do not report results for the more general specification; they are available on request). Table 6 thus shows results based on models of the form

$$
\ln w_{i}=\boldsymbol{\alpha} \mathbf{x}_{\mathbf{i}}+\bar{\beta}_{0} \cdot s_{i}+\sum_{j=1}^{3} \beta_{j} \cdot \max \left\{s_{i}-\theta_{j}, 0\right\}+\eta\left(\hat{\lambda}_{i}\right)+v_{i}
$$

Compared to the OLS results, the estimated returns for Kenya tend to increase as a result of treating education as endogenous. For the young age group the convexity gets more pronounced as a result of the instrumenting, in the sense that there are large rises in the coefficients on $\max (0, \mathrm{EDUC}-7)$ and $\max (0, \mathrm{EDUC}-10)$. For the old age group, the earnings profile becomes steeper but the shape is similar to that obtained by OLS. For both age groups we can reject both linearity of the earnings function and exogeneity at the one per cent level. These results suggest that OLS underestimates the returns to education. For the Tanzanian samples the effects of controlling for endogeneity of education are smaller, and we can

\footnotetext{
${ }^{22}$ The reported standard errors have been bootstrapped to take into account the two-step procedure.
} 
comfortably accept exogeneity. For the old age group the non-linearities in the earnings function are highly significant, and for the young age group they are marginally significant. For both age groups there is a sharp increase in the slope of the earnings function as education increases from 12 to 13 years. These results are all similar to the OLS results. For both countries we can always reject that the profile is flat - over the whole range as well as over the range 0-12 years - and we can reject linearity at the one percent level in three out of fours cases and at the 10 per cent level in the one remaining case. Similar to the OLS results, there is mixed evidence for whether linearity in the range $0-12$ years can be accepted.

A common result in the empirical literature is that the estimated returns to education increase as a result of treating education as an endogenous variable. We obtain a similar result for Kenya, which is quite contrary to the idea that unobserved ability leads to an upward bias in the estimated return to education. Why might this happen? One possibility is that education is measured with error, resulting in a downward bias in the OLS estimate. Having been present at many of the interviews ourselves, it is our impression that respondents were able to recall years of schooling both with ease and with a relatively high degree of accuracy. We would therefore be wary of attributing too large a role to reporting errors in this context.

For regression models of earnings that are linear in education, it is common to interpret the estimated returns to education in models controlling for endogeneity as a local average treatment effect (LATE). Card (2001) discusses how if there is heterogeneity in the returns to education, instrumental variable estimates may identify the returns to education for a subset of individuals with relatively high returns to education. Could a similar explanation hold in our case? If so, we would expect to find significant correlation between the slope parameter $\beta_{0 a t}\left(\lambda_{i}\right)$ and the residual from the first-stage regression. As already noted, however, we cannot reject the null that the interaction effects between the first-stage residual and education are zero. We would therefore argue that there is no strong support in the data for this explanation. 
A third possibility is that sample selectivity plays a role. OLS estimates may in fact be biased downward if the selectivity mechanism is relatively strong. Under certain assumptions that have already been discussed, the control function estimator will allow for selectivity. This could explain why the point estimate rises.

A fourth possible explanation why the control function estimates for Kenya are relatively high is that the instruments are correlated with the residual of the earnings equation. Compared to most other studies of returns to education in developing countries we would argue that our data contain what would seem, a priori, relatively good instruments. Still, it is clearly possible that in our application the instruments are invalid (see footnote 21) and the control function estimates inconsistent.

\section{Conclusions}

There is limited empirical evidence on changes in the returns to education in developing countries over long periods of time. Our data have enabled us to document changes in the returns to education in Kenya and Tanzania during the 1990s and also allowed a comparison with earlier work by Knight and Sabot (1990). It is clear that in the long run the pattern across the two countries has been very different. Kenya has seen long-run falls in the return to education at the post primary level and Tanzania has not. Indeed we find for Tanzania an increase in the return to education in the 1990s.

One of the primary hypotheses advanced to explain the increased returns to education observed in the U.S. is skill biased technical change. This is unlikely to be the reason for the changes in the returns to education in Kenya and Tanzania, as the rate of technological progress in manufacturing has been at best modest in these countries over the last decades (Bigsten, 2002; Pack, 2002). A more likely explanation can be inferred from the work of Knight and Sabot (1990), who argue that the high returns in Kenya relative to Tanzania reflected a willingness to allow market processes to work in Kenya relative to Tanzania. Over the 1990s Tanzanian polices have become much more similar to those of Kenya, and we have 
shown that by the end of the 1990s the earnings profiles were quite similar in the two countries.

The second issue on which we have focused has been the shape of the earnings function. There is strong evidence that the earnings function is convex for both Kenya and Tanzania. There are significant differences in the earnings profiles across the age groups. In Tanzania there is increasing convexity over the 1990 s, for Kenya remarkable stability. There is no evidence from our control function estimates that the finding of convexity is driven by unobserved ability. In the case of Kenya, where we can reject exogeneity at the five per cent level for both age groups, the control function estimates are generally larger than their OLS counterparts. We have discussed four possible explanations: that education is measured with error; that our instruments impact mostly on students with high returns to education; that individuals select into the manufacturing sector based on unobserved ability; and that the instruments are invalid. We would argue that selectivity is a plausible explanation, but we do not rule out the possibility that the instruments are invalid. While we cannot be sure of the source, our finding that control function estimates of the returns to education are generally larger than the OLS estimates is consistent with an increasing number of studies for both developed and developing countries. From a theoretical point of view, convexity of the earnings function implies that the cost of education must increase faster than the marginal return, or everyone would get the maximum level of education. In Africa rapidly increasing costs seems perfectly plausible. Binding credit constraints, for instance, may well drive up the shadow cost of obtaining tertiary education.

Finally, one of the micro-macro puzzles in the development literature is why at the macro level the expansion of education in Africa during the last two decades has generated so little growth, while at the micro level the average returns to education appear high. With convexity, these two results could be reconciled if the expansion of education has primarily occurred on relatively flat segments of the earnings function. 


\section{References}

Appleton, Simon, John Hoddinott, and John Knight (1996). "Primary Education as an Input into Post-primary Education: A Neglected Benefit," Oxford Bulletin of Economics and Statistics 58:1, pp. 211-19.

Appleton, Simon (2002). "Education, Incomes and Poverty in Uganda in the 1990s," paper presented at the CSAE conference Understanding Poverty and Growth in Sub-Saharan Africa at St.Catherine's College, Oxford, March 18-19, 2002.

Appleton, Simon, Arne Bigsten, and Damiano Kulundu Manda (1999). "Educational expansion and economic decline. Returns to education in Kenya 1978-1995," CSAE Working Paper 99.6. Oxford: Centre for the Study of African Economies, Oxford University.

Belzil, Christian (2004). "On the Specification of Mincerian Wage Regressions with Heterogeneity, Non-Linearity, Non-Separability, and Heteroskedasticity,” IZA Discussion Paper No. 1083. Bonn, Germany: IZA.

Belzil, Christian and Jörgen Hansen (2002). "Unobserved Ability and the Return to Schooling," Econometrica 70:5, pp.2075-2091.

Bennell, Paul (1996a). "Rates of Return to Education: Does the Conventional Pattern Prevail in Sub-Saharan Africa?" World Development 24:1, pp.183-99.

Bennell, Paul (1996b). "Using and Abusing Rate of Return: A Critique of the World Bank's 1995 Education Sector Review," International Journal of Educational Development $16: 3$, pp.235-248.

Bennell, Paul (2002). "Hitting the Target: Doubling Primary School Enrollments in SubSaharan Africa By 2015,” World Development 30:7, pp.1179-1194.

Bigsten, Arne (2002). "History and Policy of Manufacturing in Kenya," pp.7-30 in A. Bigsten and P. Kimuyu (eds.) Structure and Performance of Manufacturing in Kenya. Hampshire, UK: Palgrave.

Bigsten, Arne, Paul Collier, Stefan Dercon, Bernard Gauthier, Marcel Fafchamps, Jan Willem Gunning, Anders Isaksson, Abena Oduro, Remco Oostendorp, Catherine Pattillo, Måns 
Söderbom, Francis Teal, Albert Zeufack, and Simon Appleton (2000). "Rates of Return on Physical and Human Capital in Africa's Manufacturing Sector," Economic Development and Cultural Change 48:4, pp.801-827.

Bigsten Arne and Peter Kimuyu (eds.) (2002). Structure and Performance of Manufacturing in Kenya. Hampshire, UK: Palgrave.

Blundell, Richard and James L. Powell (2001). "Endogeneity in Nonparametric and Semiparametric Regression Models," cemmap working paper CWP09/01. London: The Institute for Fiscal Studies; Department of Economics, UCL.

Canagarajah, Sudharshan and Saji Thomas (1997). "Ghana's Labor Market (1987-92),"

Policy Research Working Paper 1752. Washington D.C: The World Bank.

Card, David (2001). "Estimating the Return to Schooling: Progress on Some Persistent Econometric Problems," Econometrica 69:5, pp.1127-1160.

Cooksey, Brian and Sibylle Riedmiller (1997). "Tanzanian Education in the Nineties: Beyond the Diploma Disease," Assessment in Education: Principles, policy \& practice 4:1, pp.121-135

Dore, Ronald (1976). The Diploma Disease. London: George Allen \& Unwin.

Duraisamy, P. (2002). "Changes in Returns to Education in India, 1983-94: By Gender, AgeCohort and Location," Economics of Education Review 21:6, pp. 609-622.

Fafchamps, Marcel, Najy Benhassine and Måns Söderbom, 2004. “Earnings and Human Capital in African Manufacturing," mimeo. Oxford: Centre for the Study of African Economies, Department of Economics, University of Oxford.

Garen, John (1984). "The Returns to Schooling: A Selectivity Bias Approach with a Continuous Choice Variable," Econometrica 52:5, pp.1199-1218.

Harding, Alan, Godius Kahyarara, and Neil Rankin (2002). "Firm Growth, Productivity and Earnings in Tanzanian Manufacturing 1992-1999," CSAE Report REP/2002-04. Oxford: Centre for the Study of African Economies, Department of Economics, University of Oxford. 
Harding, Alan, Måns Söderbom and Francis Teal (2002). "The Tanzanian Manufacturing Enterprise Survey 2002," CSAE Report REP/2002-04. Oxford: Centre for the Study of African Economies, Department of Economics, University of Oxford.

Hahn, Jinyong and Jerry Hausman (2003). "Weak Instruments: Diagnosis and Cures in Empirical Economics," American Economic Review 93:2, pp.118-125.

Heckman, James J. (1976). "The Common Structure of Statistical Models of Truncation, Sample Selection, and Limited Dependent Variables and a Simple Estimator for Such Models," Annals of Economic and Social Measurement 5, pp.475-592.

Heckman, James J. (1979). “Sample Selection Bias as a Specification Error,” Econometrica 47:1, pp.153-161.

Katz, Lawrence F. and David H. Autor (1999) “Changes in the Wage Structure and Earnings Inequality," in O. Ashenfelter and D. Card (eds.) Handbook of Labor Economics, Volume 3A. Amsterdam; New York: North Holland.

Kingdon, Geeta Gandhi and Jeemol Unni (2001). “Education and Women's Labour Market Outcomes in India," Education Economics 9:2, pp.173-194.

Knight, John B. and Richard H. Sabot (1990). Education, Productivity and Inequality: The East African Natural Experiment. Oxford: Oxford University Press. Published for the World Bank.

Krishnan, Pramila, Tesfaye Gebre Selassie, and Stefan Dercon (1998). “The Urban Labour Market During Structural Adjustment: Ethiopia 1990-97," CSAE Working Paper 98.9. Oxford: Centre for the Study of African economies, University of Oxford.

Moll, P.G. (1996), The Collapse of Primary Schooling Returns in South Africa 1960-90,” Oxford Bulletin of Economics and Statistics 58:1, pp.185-210.

Pack, Howard (2002). “Africa's Declining Productivity: Evidence from Tanzania,” mimeo, University of Pennsylvania.

Psacharopoulos, George (1994). "Returns to Investment in Education: A Global Update," World Development 22:9, pp. 1325-1343. 
Psacharopoulos, George and Harry Anthony Patrinos (2002). "Returns to Investment in Education: A Further Update,” World Bank Research Working Paper 2881.

Washington D.C: The World Bank.

Söderbom, Måns (2001). “Constraints and Opportunities in Kenyan Manufacturing: Report on the Kenyan Manufacturing Enterprise Survey 2000," CSAE Report REP/2001-03. Oxford: Centre for the Study of African Economies, Department of Economics, University of Oxford.

Söderbom, Måns and Francis Teal (2004). "Size and Efficiency in African Manufacturing Firms: Evidence from Firm-Level Panel Data," Journal of Development Economics 73, pp.36-394.

Söderbom, Måns, Francis Teal, and Anthony Wambugu (2005). "Unobserved Heterogeneity and the Relation between Earnings and Firm Size: Evidence from Two Developing Countries," Economics Letters, forthcoming

Squire, Lyn and Sethaput Suthiwart-Narueput (1997). "The Impact of Labor Market Regulations," World Bank Economic Review 11:1, pp.119-43.

StataCorp (2003). Stata Statistical Software: Release 8.0. College Station, TX: Stata Corporation.

Toyoda, Toshio (1997). “Kenya 1975-1995: An Introductory Note on Educational Expansion," Assessment in Education: Principles, policy \& practice 4:1, pp.87-90.

Trostel, Philip, Ian Walker and Paul Woolley (2002). "Estimates of the Economic Return to Schooling for 28 Countries," Labour Economics 9:1, pp.1-16.

Wooldridge, Jeffrey M. (2002a). "Unobserved Heterogeneity and Estimation of Average Partial Effects," mimeo. East Lansing, MI: Michigan State University.

Wooldrigde, Jeffrey M. (2002b). Econometric Analysis of Cross-Section and Panel Data. London, England; Cambridge Massachusetts: The MIT Press.

World Bank (1995). "Priorities and Strategies for Education: A World Bank Sector Review," Washington, D.C: The World Bank, Education and Social Policy Department. 


\section{TABLE 1}

\section{SUMMARY STATISTICS}

\begin{tabular}{|c|c|c|c|c|}
\hline & \multicolumn{2}{|c|}{ Kenya } & \multicolumn{2}{|c|}{ Tanzania } \\
\hline & Mean & Standard Dev. & Mean & Standard Dev. \\
\hline Earnings ${ }^{(1)}$ & 74.6 & 117.4 & 54.7 & 71.2 \\
\hline Years of Education & 9.1 & 2.9 & 8.8 & 3.5 \\
\hline Age & 33.9 & 9.1 & 35.5 & 10.0 \\
\hline Years of Tenure & 7.9 & 7.2 & 8.1 & 7.3 \\
\hline Male Dummy & 0.85 & & 0.80 & \\
\hline Works in Capital City & 0.64 & & 0.44 & \\
\hline Old Age group ${ }^{(2)}$ & 0.57 & & 0.63 & \\
\hline Observations & 4039 & & 2738 & \\
\hline
\end{tabular}

(1) Monthly earnings expressed in constant 1993 USD.

(2) An individual belongs to the old age group if he or she is more than 30 years old. 
TABLE 2

EARNINGS AND EDUCATION IN KENYAN MANUFACTURING

\begin{tabular}{|c|c|c|c|c|}
\hline & \multicolumn{2}{|c|}{1993} & \multicolumn{2}{|c|}{1994} \\
\hline & [1] Young & [2] Old & [3 Young & [4] Old \\
\hline Age & $\begin{array}{c}0.035 \\
(0.200)\end{array}$ & $\begin{array}{c}0.052 \\
(0.039)\end{array}$ & $\begin{array}{l}-0.021 \\
(0.123)\end{array}$ & $\begin{array}{c}0.026 \\
(0.037)\end{array}$ \\
\hline Age squared/100 & $\begin{array}{l}-0.024 \\
(0.387)\end{array}$ & $\begin{array}{l}-0.032 \\
(0.048)\end{array}$ & $\begin{array}{c}0.075 \\
(0.247)\end{array}$ & $\begin{array}{l}-0.019 \\
(0.042)\end{array}$ \\
\hline Tenure & $\begin{array}{l}-0.002 \\
(0.011)\end{array}$ & $\begin{array}{c}0.001 \\
(0.004)\end{array}$ & $\begin{array}{c}0.021 \\
(0.013)\end{array}$ & $\begin{array}{c}0.012 \\
(0.005)^{*}\end{array}$ \\
\hline Male & $\begin{array}{l}-0.001 \\
(0.082)\end{array}$ & $\begin{array}{c}0.135 \\
(0.089)\end{array}$ & $\begin{array}{l}-0.021 \\
(0.068)\end{array}$ & $\begin{array}{c}0.088 \\
(0.095)\end{array}$ \\
\hline Capital city & $\begin{array}{l}0.367 \\
(0.071)^{* *}\end{array}$ & $\begin{array}{c}0.320 \\
(0.063)^{* *}\end{array}$ & $\begin{array}{c}0.287 \\
(0.068)^{* *}\end{array}$ & $\begin{array}{c}0.368 \\
(0.071)^{* *}\end{array}$ \\
\hline Education & $\begin{array}{c}0.027 \\
(0.023)\end{array}$ & $\begin{array}{c}0.061 \\
(0.017)^{* *}\end{array}$ & $\begin{array}{c}0.023 \\
(0.021)\end{array}$ & $\begin{array}{c}0.038 \\
(0.019)^{*}\end{array}$ \\
\hline $\max (0$, EDUC-7) & $\begin{array}{l}-0.041 \\
(0.043)\end{array}$ & $\begin{array}{c}0.027 \\
(0.040)\end{array}$ & $\begin{array}{c}0.003 \\
(0.042)\end{array}$ & $\begin{array}{c}0.006 \\
(0.046)\end{array}$ \\
\hline $\max (0$, EDUC-10) & $\begin{array}{l}0.247 \\
(0.093)^{* *}\end{array}$ & $\begin{array}{c}0.136 \\
(0.085)\end{array}$ & $\begin{array}{c}0.060 \\
(0.090)\end{array}$ & $\begin{array}{c}0.220 \\
(0.120)^{+}\end{array}$ \\
\hline $\max (0$, EDUC-12) & $\begin{array}{l}-0.009 \\
(0.120)\end{array}$ & $\begin{array}{c}0.064 \\
(0.093)\end{array}$ & $\begin{array}{c}0.083 \\
(0.100)\end{array}$ & $\begin{array}{l}-0.194 \\
(0.205)\end{array}$ \\
\hline \multicolumn{5}{|l|}{ Tests ( $p$-values) } \\
\hline Earnings profile flat & 0.000 & 0.000 & 0.000 & 0.000 \\
\hline Earnings profile linear & 0.000 & 0.000 & 0.014 & 0.011 \\
\hline Education $\leq 12$ : Earnings profile flat & 0.000 & 0.000 & 0.001 & 0.000 \\
\hline Education $\leq 12$ : Earnings profile linear & 0.019 & 0.010 & 0.679 & 0.034 \\
\hline R-squared & 0.288 & 0.374 & 0.182 & 0.261 \\
\hline Observations & 429 & 675 & 460 & 488 \\
\hline
\end{tabular}

The table continues on the next page. 
TABLE 2 CONTINUED

EARNINGS AND EDUCATION IN KENYAN MANUFACTURING

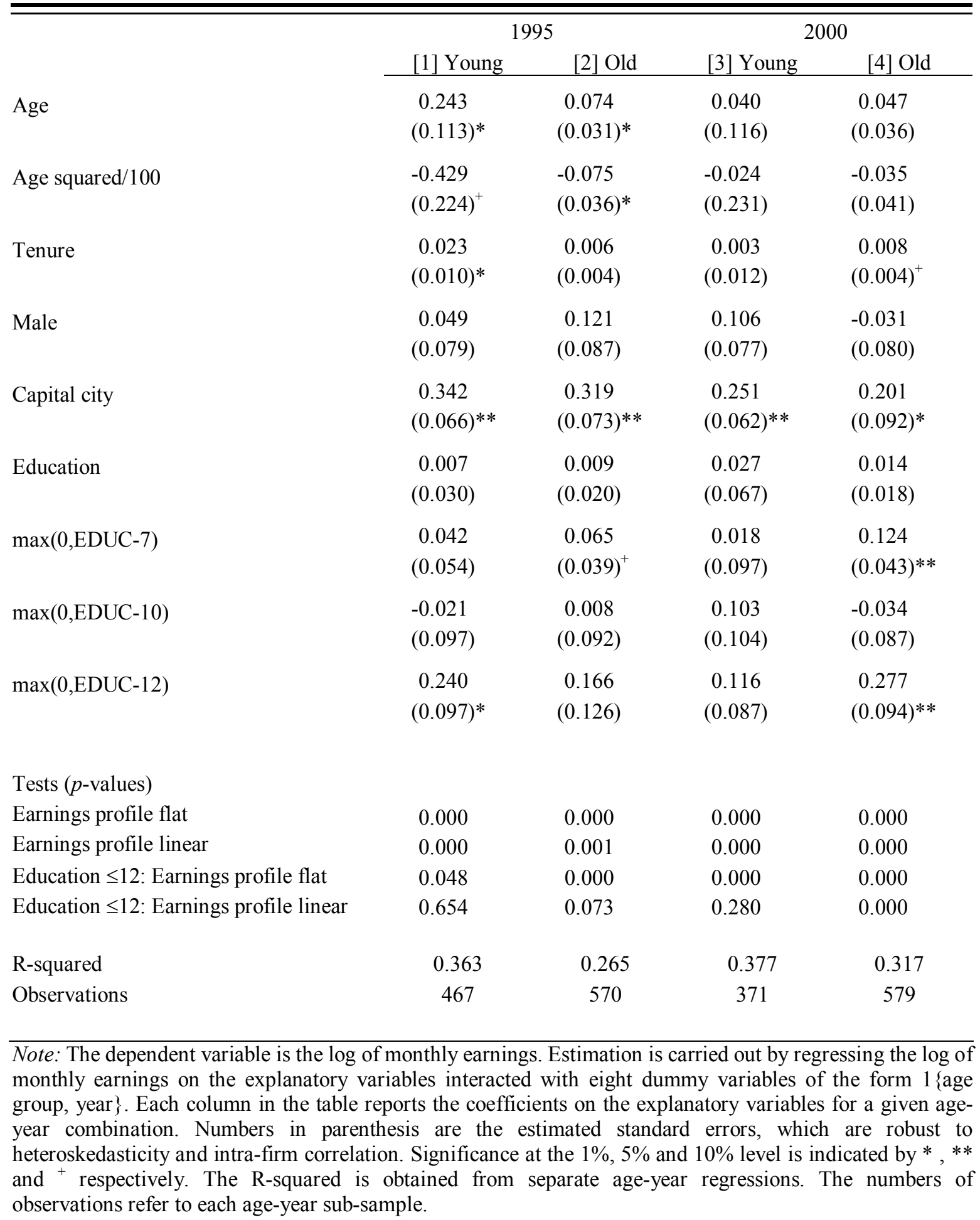


TABLE 3

EARNINGS AND EDUCATION IN TANZANIAN MANUFACTURING

\begin{tabular}{|c|c|c|c|c|}
\hline & \multicolumn{2}{|c|}{1993} & \multicolumn{2}{|c|}{1994} \\
\hline & [1] Young & [2] Old & [3] Young & [4] Old \\
\hline Age & $\begin{array}{c}0.035 \\
(0.112)\end{array}$ & $\begin{array}{l}-0.006 \\
(0.034)\end{array}$ & $\begin{array}{l}-0.068 \\
(0.177)\end{array}$ & $\begin{array}{c}0.043 \\
(0.047)\end{array}$ \\
\hline Age squared/100 & $\begin{array}{l}-0.016 \\
(0.225)\end{array}$ & $\begin{array}{c}0.020 \\
(0.038)\end{array}$ & $\begin{array}{c}0.179 \\
(0.362)\end{array}$ & $\begin{array}{l}-0.036 \\
(0.051)\end{array}$ \\
\hline Tenure & $\begin{array}{c}0.004 \\
(0.014)\end{array}$ & $\begin{array}{l}-0.001 \\
(0.004)\end{array}$ & $\begin{array}{c}0.008 \\
(0.020)\end{array}$ & $\begin{array}{c}0.005 \\
(0.008)\end{array}$ \\
\hline Male & $\begin{array}{c}0.044 \\
(0.069)\end{array}$ & $\begin{array}{c}0.186 \\
(0.082)^{*}\end{array}$ & $\begin{array}{c}0.083 \\
(0.092)\end{array}$ & $\begin{array}{c}0.160 \\
(0.083)^{+}\end{array}$ \\
\hline Capital city & $\begin{array}{c}0.068 \\
(0.082)\end{array}$ & $\begin{array}{c}0.194 \\
(0.078)^{*}\end{array}$ & $\begin{array}{c}0.279 \\
(0.132)^{*}\end{array}$ & $\begin{array}{l}0.371 \\
(0.123)^{* *}\end{array}$ \\
\hline Education & $\begin{array}{c}0.055 \\
(0.029)^{+}\end{array}$ & $\begin{array}{c}0.034 \\
(0.016)^{*}\end{array}$ & $\begin{array}{c}0.019 \\
(0.045)\end{array}$ & $\begin{array}{c}0.042 \\
(0.029)\end{array}$ \\
\hline $\max (0$, EDUC-7) & $\begin{array}{l}-0.012 \\
(0.053)\end{array}$ & $\begin{array}{c}0.048 \\
(0.043)\end{array}$ & $\begin{array}{c}0.058 \\
(0.091)\end{array}$ & $\begin{array}{l}-0.024 \\
(0.064)\end{array}$ \\
\hline $\max (0$, EDUC-10) & $\begin{array}{c}0.005 \\
(0.118)\end{array}$ & $\begin{array}{c}0.076 \\
(0.099)\end{array}$ & $\begin{array}{l}-0.209 \\
(0.189)\end{array}$ & $\begin{array}{c}0.216 \\
(0.149)\end{array}$ \\
\hline $\max (0$, EDUC-12) & $\begin{array}{c}0.085 \\
(0.174)\end{array}$ & $\begin{array}{l}-0.076 \\
(0.093)\end{array}$ & $\begin{array}{c}0.561 \\
(0.279)^{*}\end{array}$ & $\begin{array}{l}-0.122 \\
(0.142)\end{array}$ \\
\hline \multicolumn{5}{|l|}{ Tests ( $p$-values): } \\
\hline Earnings profile flat & 0.000 & 0.000 & 0.003 & 0.000 \\
\hline Earnings profile linear & 0.740 & 0.006 & 0.057 & 0.029 \\
\hline Education $\leq 12$ : Earnings profile flat & 0.015 & 0.000 & 0.422 & 0.007 \\
\hline Education $\leq 12$ : Earnings profile linear & 0.970 & 0.008 & 0.541 & 0.153 \\
\hline R-squared & 0.140 & 0.318 & 0.250 & 0.318 \\
\hline Observations & 304 & 601 & 176 & 268 \\
\hline
\end{tabular}

The table continues on the next page. 
TABLE 3 CONTINUED

EARNINGS AND EDUCATION IN TANZANIAN MANUFACTURING

\begin{tabular}{|c|c|c|c|c|}
\hline & \multicolumn{2}{|c|}{1999} & \multicolumn{2}{|c|}{2001} \\
\hline & [1] Young & [2] Old & [3] Young & [4] Old \\
\hline Age & $\begin{array}{c}0.220 \\
(0.121)^{+}\end{array}$ & $\begin{array}{c}0.060 \\
(0.036)^{+}\end{array}$ & $\begin{array}{c}0.265 \\
(0.152)^{+}\end{array}$ & $\begin{array}{c}0.014 \\
(0.037)\end{array}$ \\
\hline Age squared/100 & $\begin{array}{l}-0.374 \\
(0.240)\end{array}$ & $\begin{array}{l}-0.052 \\
(0.040)\end{array}$ & $\begin{array}{l}-0.460 \\
(0.299)\end{array}$ & $\begin{array}{l}-0.011 \\
(0.040)\end{array}$ \\
\hline Tenure & $\begin{array}{l}-0.018 \\
(0.011)^{+}\end{array}$ & $\begin{array}{l}-0.000 \\
(0.005)\end{array}$ & $\begin{array}{c}0.004 \\
(0.014)\end{array}$ & $\begin{array}{c}0.004 \\
(0.004)\end{array}$ \\
\hline Male & $\begin{array}{c}0.063 \\
(0.080)\end{array}$ & $\begin{array}{l}-0.098 \\
(0.129)\end{array}$ & $\begin{array}{l}0.270 \\
(0.083)^{* *}\end{array}$ & $\begin{array}{c}0.058 \\
(0.074)\end{array}$ \\
\hline Capital city & $\begin{array}{c}0.171 \\
(0.089)^{+}\end{array}$ & $\begin{array}{c}0.119 \\
(0.101)\end{array}$ & $\begin{array}{c}0.271 \\
(0.087)^{* *}\end{array}$ & $\begin{array}{c}0.184 \\
(0.088)^{*}\end{array}$ \\
\hline Education & $\begin{array}{l}-0.010 \\
(0.014)\end{array}$ & $\begin{array}{c}0.061 \\
(0.017)^{* *}\end{array}$ & $\begin{array}{c}0.053 \\
(0.017)^{* *}\end{array}$ & $\begin{array}{c}0.030 \\
(0.018)^{+}\end{array}$ \\
\hline $\max (0$, EDUC-7) & $\begin{array}{c}0.047 \\
(0.041)\end{array}$ & $\begin{array}{c}0.031 \\
(0.035)\end{array}$ & $\begin{array}{c}0.068 \\
(0.058)\end{array}$ & $\begin{array}{c}0.087 \\
(0.042)^{*}\end{array}$ \\
\hline $\max (0$, EDUC-10) & $\begin{array}{l}-0.043 \\
(0.137)\end{array}$ & $\begin{array}{l}-0.016 \\
(0.129)\end{array}$ & $\begin{array}{l}-0.297 \\
(0.169)^{+}\end{array}$ & $\begin{array}{l}-0.083 \\
(0.118)\end{array}$ \\
\hline $\max (0$, EDUC-12) & $\begin{array}{c}0.216 \\
(0.170)\end{array}$ & $\begin{array}{c}0.231 \\
(0.188)\end{array}$ & $\begin{array}{c}0.469 \\
(0.177)^{* *}\end{array}$ & $\begin{array}{c}0.269 \\
(0.154)^{+}\end{array}$ \\
\hline Tests ( $p$-values): & & & & \\
\hline Earnings profile flat & 0.002 & 0.000 & 0.000 & 0.000 \\
\hline Earnings profile linear & 0.003 & 0.000 & 0.012 & 0.000 \\
\hline Education $\leq 12$ : Earnings profile flat & 0.570 & 0.000 & 0.000 & 0.000 \\
\hline Education $\leq 12$ : Earnings profile linear & 0.370 & 0.630 & 0.179 & 0.079 \\
\hline R-squared & 0.207 & 0.417 & 0.304 & 0.389 \\
\hline Observations & 297 & 433 & 227 & 432 \\
\hline
\end{tabular}

See Table 2 for notes. 
TABLE 4

MARginal RETURnS To EdUCATION: COMPARATIVE ANALYSIS

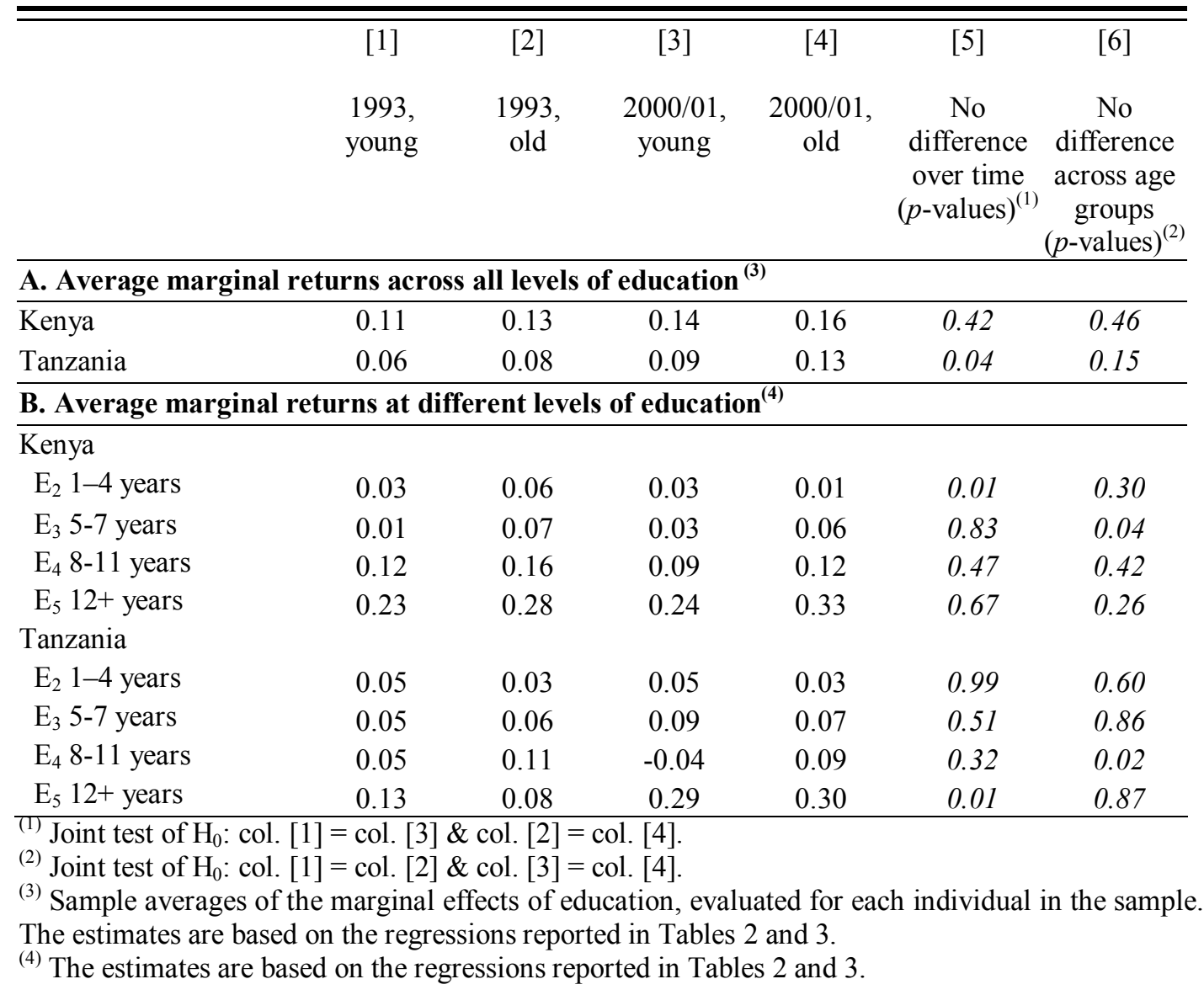




\section{TABLE 5}

\section{Predicted EARNings DifFerentials ANd EdUCATION: COMPARATIVE ANALYSIS}

\begin{tabular}{|c|c|c|c|c|c|c|c|}
\hline & [1] & {$[2]$} & [3] & [4] & [5] & [6] & [7] \\
\hline & $\begin{array}{l}1993, \\
\text { young }\end{array}$ & $\begin{array}{c}1993, \\
\text { old }\end{array}$ & $\begin{array}{c}2000 / 01 \\
\text { young }\end{array}$ & $\begin{array}{c}2000 / 01 \\
\text { old }\end{array}$ & $\begin{array}{c}\text { No } \\
\text { difference } \\
\text { over time } \\
{\text { (p-values })^{(1)}}\end{array}$ & $\begin{array}{c}\text { No } \\
\text { difference } \\
\text { across age } \\
\text { groups } \\
(p \text {-values })^{(2)}\end{array}$ & $1980^{(3)}$ \\
\hline \multicolumn{8}{|c|}{ A. Earnings differentials. Baseline: No education ${ }^{(4)}$} \\
\hline \multicolumn{8}{|l|}{ Kenya } \\
\hline $\mathrm{E}_{2} 1-4$ years & 0.09 & 0.20 & 0.09 & 0.05 & 0.15 & 0.47 & 0.18 \\
\hline$E_{3} 5-7$ years & 0.18 & 0.41 & 0.18 & 0.09 & 0.15 & 0.47 & 0.38 \\
\hline $\mathrm{E}_{4} 8-11$ years & 0.15 & 0.68 & 0.31 & 0.49 & 0.52 & 0.03 & 0.86 \\
\hline $\mathrm{E}_{5} 12+$ years & 0.88 & 1.49 & 0.94 & 1.18 & 0.23 & 0.01 & 1.62 \\
\hline \multicolumn{8}{|l|}{ Tanzania } \\
\hline $\mathrm{E}_{2} 1-4$ years & 0.20 & 0.13 & 0.19 & 0.11 & 0.99 & 0.56 & 0.06 \\
\hline $\mathrm{E}_{3} 5-7$ years & 0.38 & 0.24 & 0.37 & 0.21 & 0.99 & 0.56 & 0.28 \\
\hline $\mathrm{E}_{4} 8-11$ years & 0.50 & 0.46 & 0.70 & 0.53 & 0.72 & 0.74 & 0.64 \\
\hline$E_{5} 12+$ years & 0.88 & 0.96 & 0.97 & 1.24 & 0.32 & 0.35 & 1.04 \\
\hline \multicolumn{8}{|c|}{ B. Earnings differentials. Baseline: $E_{3}$ 5-7 years ${ }^{(5)}$} \\
\hline \multicolumn{8}{|l|}{ Kenya } \\
\hline $\mathrm{E}_{4} 8-11$ years & -0.03 & 0.27 & 0.14 & 0.39 & 0.41 & 0.01 & 0.48 \\
\hline $\mathrm{E}_{5} 12+$ years & 0.70 & 1.08 & 0.76 & 1.08 & 0.90 & 0.00 & 1.24 \\
\hline \multicolumn{8}{|l|}{ Tanzania } \\
\hline $\mathrm{E}_{4} 8-11$ years & 0.12 & 0.22 & 0.33 & 0.32 & 0.40 & 0.74 & 0.36 \\
\hline$E_{5} 12+$ years & 0.50 & 0.73 & 0.60 & 1.03 & 0.05 & 0.00 & 0.76 \\
\hline \multicolumn{8}{|c|}{$\begin{array}{l}\text { (1) Joint test of } \mathrm{H}_{0} \text { : col. [1] = col. [3] \& col. [2] = col. [4]. } \\
\text { (2) Joint test of } \mathrm{H}_{0} \text { : col. [1] = col. [2] \& col. [3] = col. [4]. } \\
\text { (3) These estimates are based on Knight and Sabot (1990), Table 6-2, column } 3 \text {. } \\
\text { (4) Predicted log earnings differentials between given levels of education and the baseline level, which is no } \\
\text { education. For example, the predicted earnings of a Kenyan individual in the young age group in } 1993 \text { with } 1-4 \\
\text { years of education is } 0.09 \text { log points higher than an otherwise identical individual without education. This } \\
\text { corresponds to a differential of about exp }(.09)-1=9 \text { per cent. The estimates are based on the regressions reported } \\
\text { in Tables } 2 \text { and } 3 \text {. } \\
\text { (5) As panel B except that the baseline is } \mathrm{E}_{3} 5-7 \text { years of education. The estimates are based on the regressions } \\
\text { reported in Tables } 2 \text { and } 3 \text {. }\end{array}$} \\
\hline
\end{tabular}


TABLE 6

CONTROL FUNCTION ESTIMATES: KENYA 2000 AND TANZANIA 2001

\begin{tabular}{|c|c|c|c|c|}
\hline & \multicolumn{2}{|c|}{ Kenya } & \multicolumn{2}{|c|}{ Tanzania } \\
\hline & [1] Young & [2] Old & [3] Young & [4] Old \\
\hline \multirow[t]{2}{*}{ Age } & -0.031 & 0.029 & 0.289 & 0.008 \\
\hline & $(0.127)$ & $(0.047)$ & $(0.142)^{*}$ & $(0.038)$ \\
\hline \multirow[t]{2}{*}{ Age squared/100 } & 0.062 & -0.004 & -0.532 & -0.004 \\
\hline & $(0.250)$ & $(0.054)$ & $(0.281)^{+}$ & $(0.043)$ \\
\hline \multirow[t]{2}{*}{ Tenure } & 0.026 & 0.013 & 0.012 & 0.005 \\
\hline & $(0.014)^{+}$ & $(0.005)^{* *}$ & $(0.017)$ & $(0.004)$ \\
\hline \multirow[t]{2}{*}{ Male } & 0.270 & 0.005 & 0.352 & 0.068 \\
\hline & $(0.094)^{* *}$ & $(0.080)$ & $(0.086)^{* *}$ & $(0.080)$ \\
\hline \multirow[t]{2}{*}{ Capital city } & 0.234 & 0.207 & 0.248 & 0.183 \\
\hline & $(0.060)^{* *}$ & $(0.093)^{*}$ & $(0.088)^{* *}$ & $(0.091)^{*}$ \\
\hline \multirow[t]{2}{*}{ Education } & -0.060 & 0.113 & 0.106 & 0.022 \\
\hline & $(0.169)$ & $(0.052)^{*}$ & $(0.063)^{+}$ & $(0.038)$ \\
\hline \multirow[t]{2}{*}{$\max (0, \mathrm{EDUC}-7)$} & 0.202 & 0.109 & 0.050 & 0.115 \\
\hline & $(0.182)$ & $(0.060)^{+}$ & $(0.086)$ & $(0.049)^{*}$ \\
\hline \multirow[t]{2}{*}{$\max (0, \mathrm{EDUC}-10)$} & 0.154 & -0.035 & -0.280 & -0.081 \\
\hline & $(0.098)$ & $(0.086)$ & $(0.189)$ & $(0.121)$ \\
\hline \multirow[t]{2}{*}{$\max (0, E D U C-12)$} & 0.099 & 0.313 & 0.463 & 0.258 \\
\hline & $(0.099)$ & $(0.098)^{* *}$ & $(0.196)^{*}$ & $(0.181)$ \\
\hline \multicolumn{5}{|l|}{ Tests ( $p$-values) } \\
\hline Earnings profile flat & 0.00 & 0.00 & 0.00 & 0.00 \\
\hline Earnings profile linear & 0.00 & 0.00 & 0.06 & 0.00 \\
\hline Education $\leq 12$ : Earnings profile flat & 0.00 & 0.00 & 0.03 & 0.00 \\
\hline Education $\leq 12$ : Earnings profile linear & 0.05 & 0.12 & 0.31 & 0.04 \\
\hline $\operatorname{EXCRES}^{(1)}$ & 0.00 & 0.00 & 0.00 & 0.00 \\
\hline RETHET $^{(2)}$ & 0.16 & 0.60 & 0.95 & 0.61 \\
\hline $\mathrm{EXOGEN}^{(3)}$ & 0.00 & 0.00 & 0.35 & 0.58 \\
\hline Observations & 371 & 579 & 227 & 432 \\
\hline
\end{tabular}

Note: The dependent variable the log of monthly earnings. Education is endogenous. Bootstrapped standard errors, robust to heteroskedasticity and intra-firm correlation are reported in parenthesis. Significance at the $1 \%, 5 \%$ and $10 \%$ level is indicated by $*, * *$ and ${ }^{+}$respectively. The explanatory variables in the regression modelling education (step 1) are: dummy variables for mother's and father's education (none; primary; middle (pre 1964) or training college; O level; A level; vocational/technical; university; don't know) and occupation (farming, fishing, forestry; trading, self-employed; clerical; employed in construction, tailoring, or worked as foreman; professional; watchman, soldier; don't know); dummy variables for distance to primary school at the age of six and to secondary school at the age of twelve (less than $1 \mathrm{~km}$; 1-3 km; 3-6 km; 6-10 km; more than $10 \mathrm{~km}$; don't know); and age, age squared, tenure, male, capital city.

(1) Wald test for joint significance of the identifying instruments in step 1 (the exclusion restrictions).

(2) Wald test for joint significance of the interaction terms between education and a third degree polynomial in the first stage residual.

(3) Wald test for joint significance of a third degree polynomial in the first stage residual. 
FIGURE 1

SAMPle Distributions of Log EARNingS

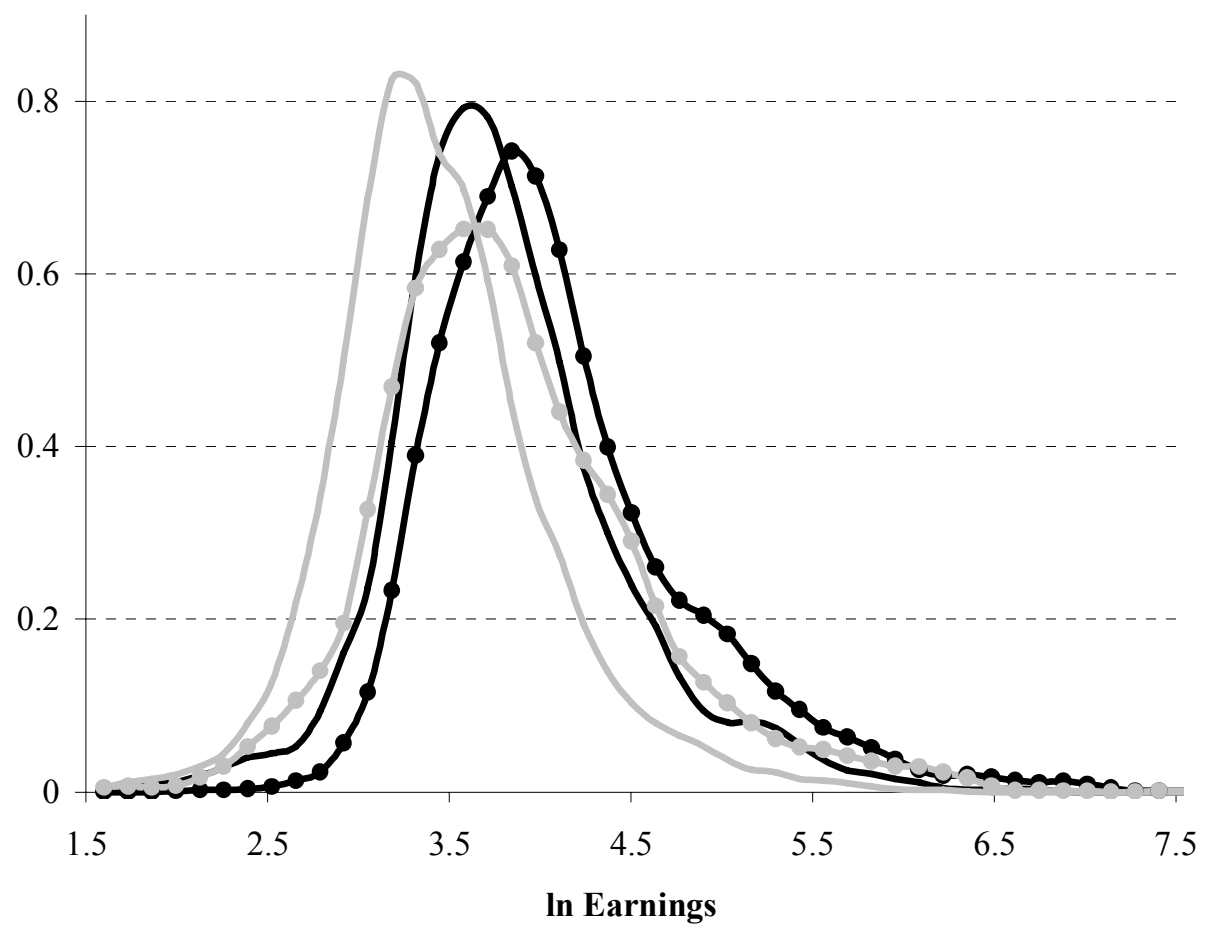

$\longrightarrow$ Kenya, young $\longrightarrow$ Kenya, old $\longrightarrow$ Tanzania, young $\longrightarrow$ Tanzania, old

Note: The density estimates were obtained using the Stata 8.0 command 'kdensity' (StataCorp, 2003). 
FIGURE 2

SAMPLE DistribUtions OF YEARS OF EDUCATION

i) Kenya

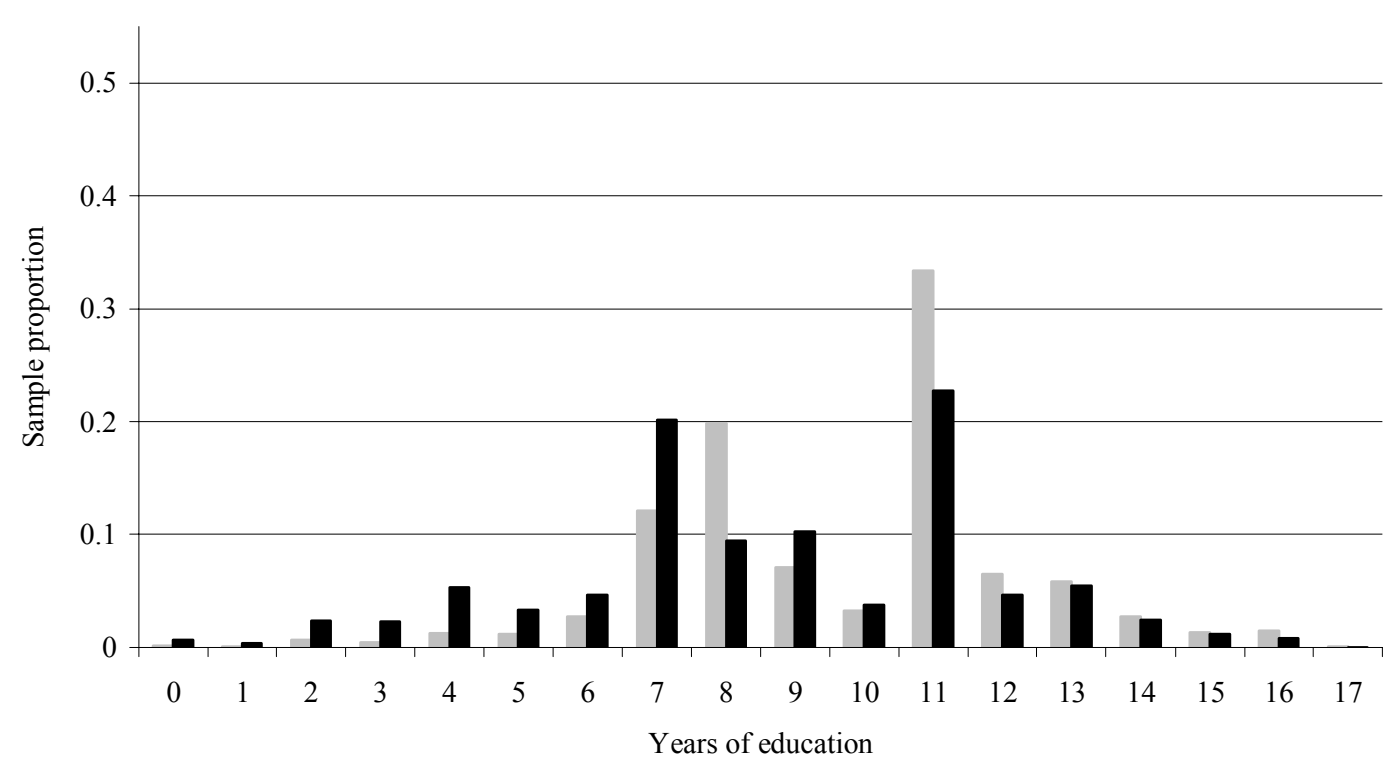

Young $\square$ Old

ii) Tanzania

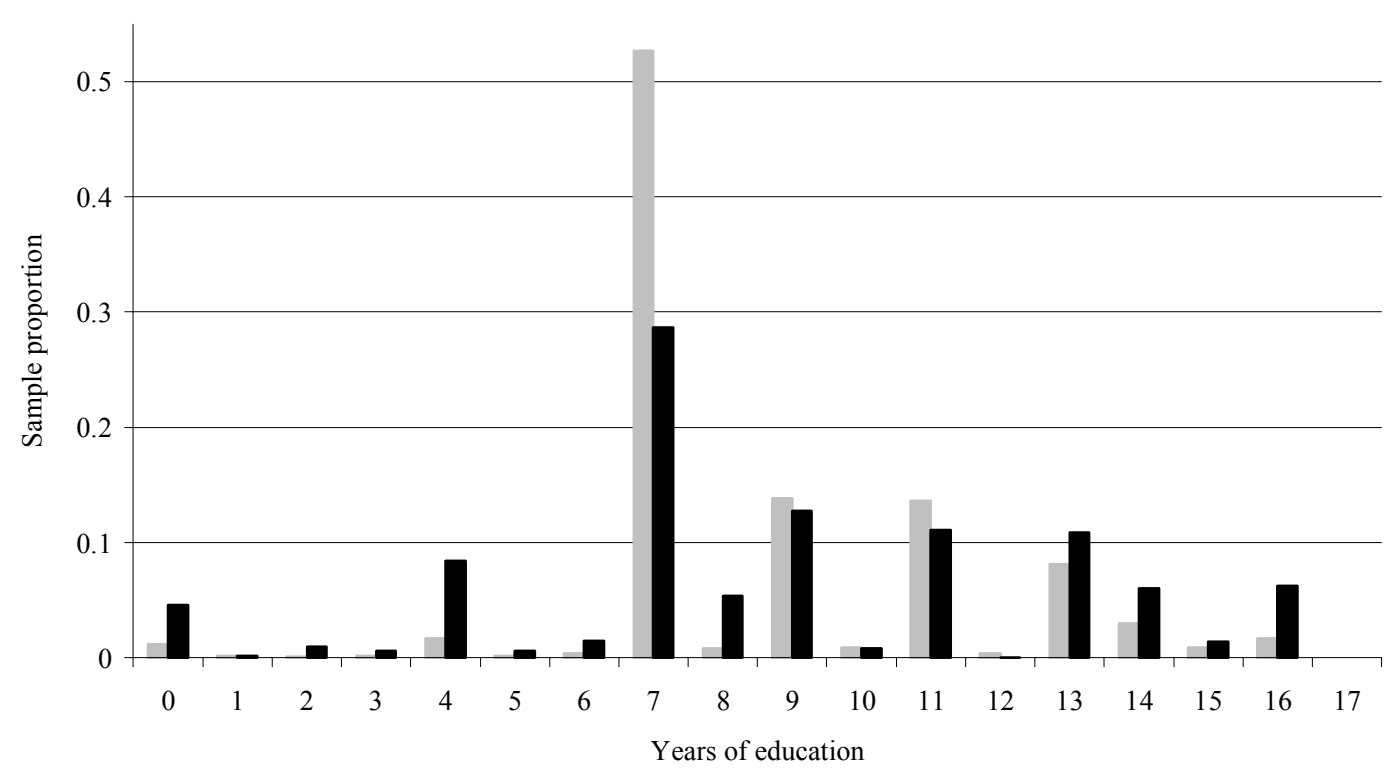

$\square$ Young $\square$ Old 
Figure 3A

EARNINGS AND EDUCATION: KENYA

i) Age group: Young

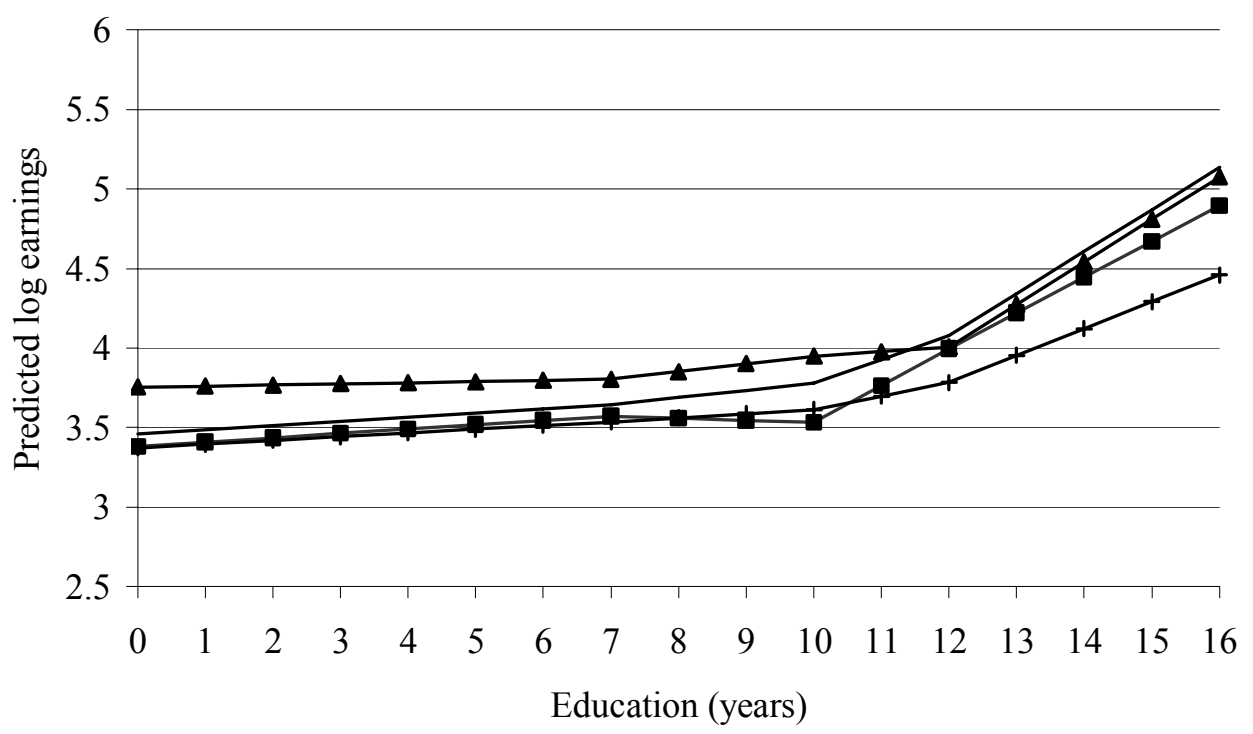

$\rightarrow$ Year $1 \rightarrow$ Year $2 \rightarrow$ Year $3-$ Year 4

ii) Age group: Old

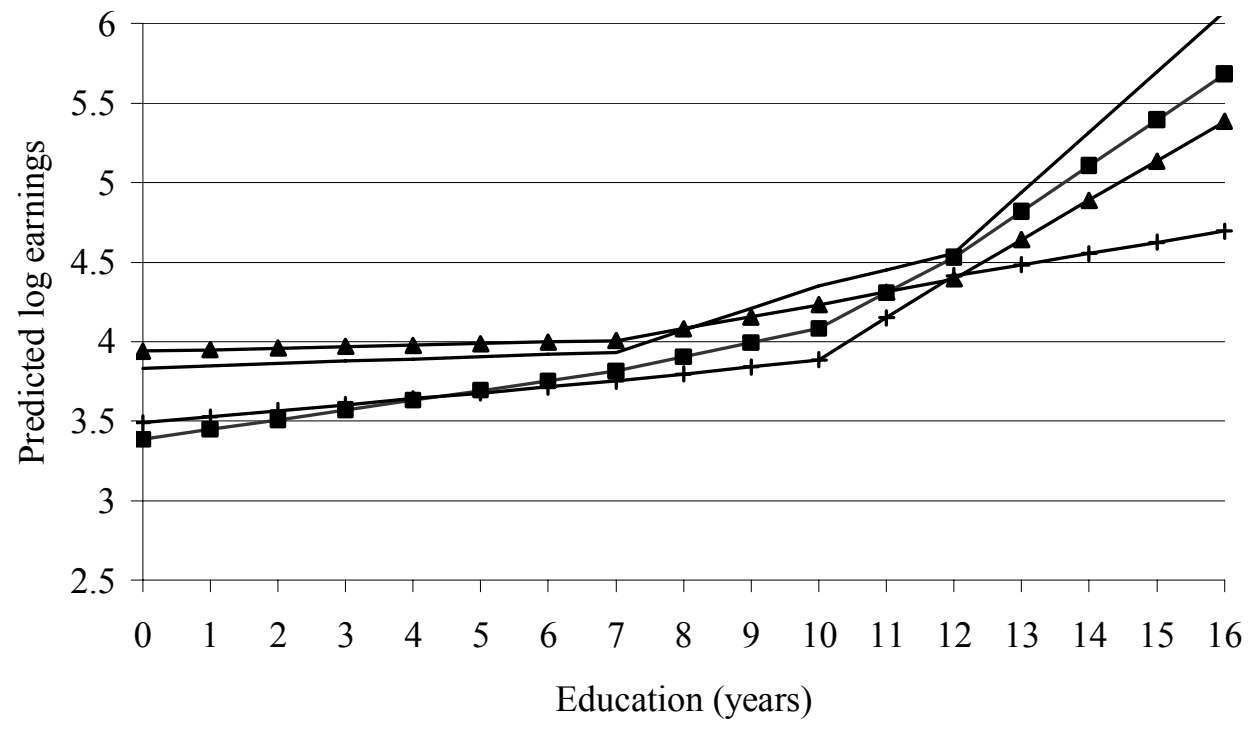

$\rightarrow-$ Year $1 \rightarrow$ Year $2 \rightarrow$ Year $3 \longrightarrow$ Year 4

Note: Year 1 = 1993; Year 2 = 1994; Year 3 = 1995; Year 4 = 2000. 
FIGURE 3B

EARNINGS AND EDUCATION: TANZANIA

i) Age group: Young

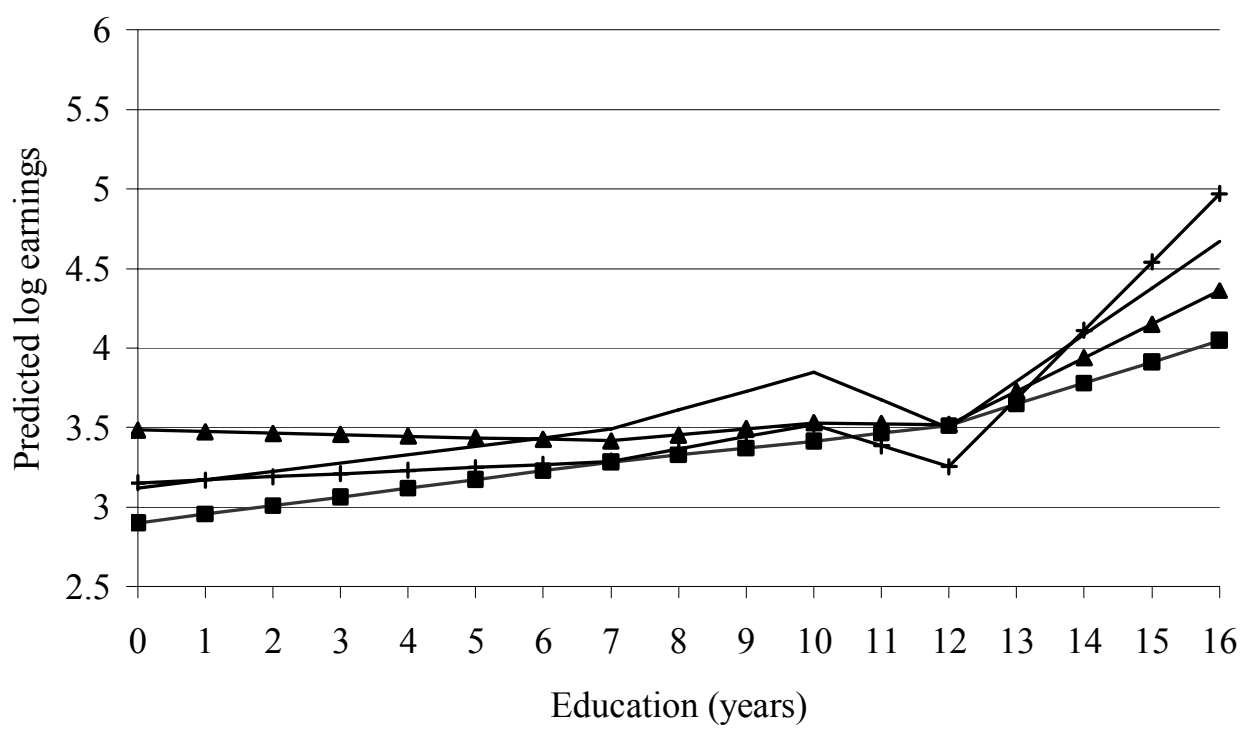

$\rightarrow$ Year $1 \rightarrow$ Year $2 \rightarrow$ Year $3-$ Year 4

ii) Age group: Old

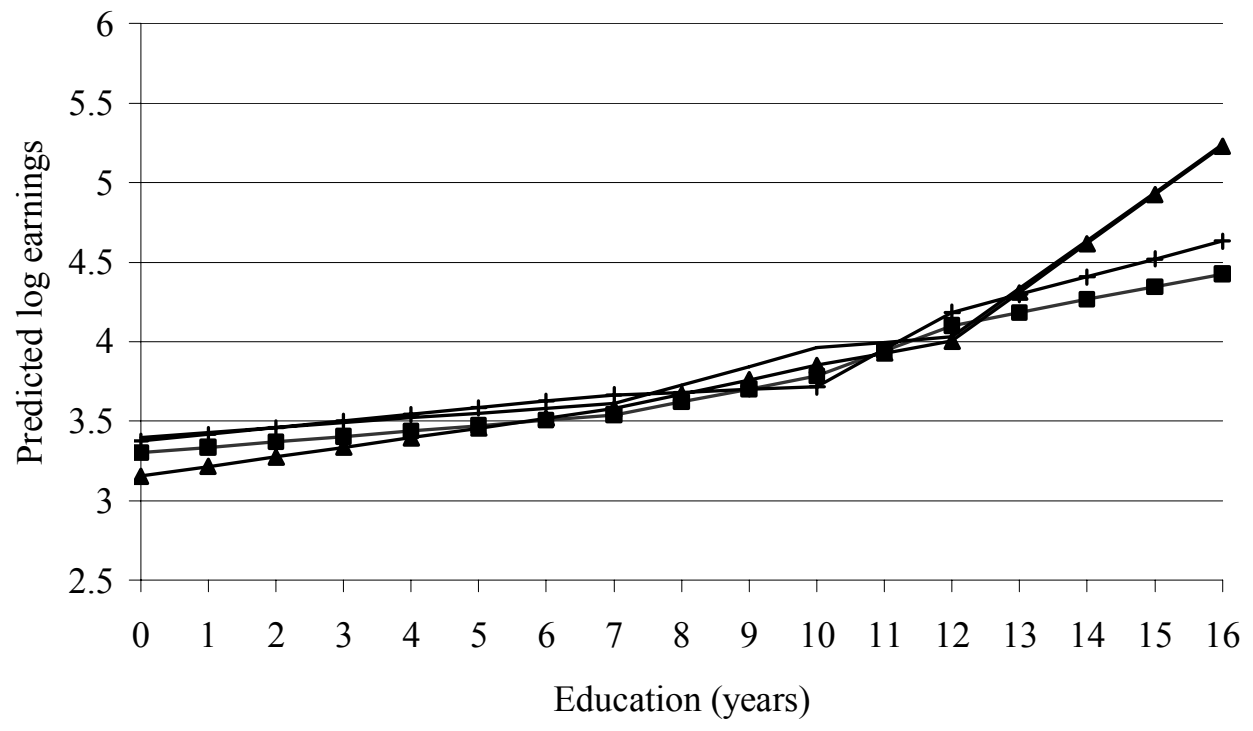

$\rightarrow-$ Year $1 \rightarrow$ Year $2 \rightarrow$ Year $3 \longrightarrow$ Year 4

Note: Year 1 = 1993; Year 2 = 1994; Year 3 = 1999; Year 4 = 2001. 
FIGURE 4A

Earnings and Education, Polynomial Specification: Kenya

i) Age group: Young

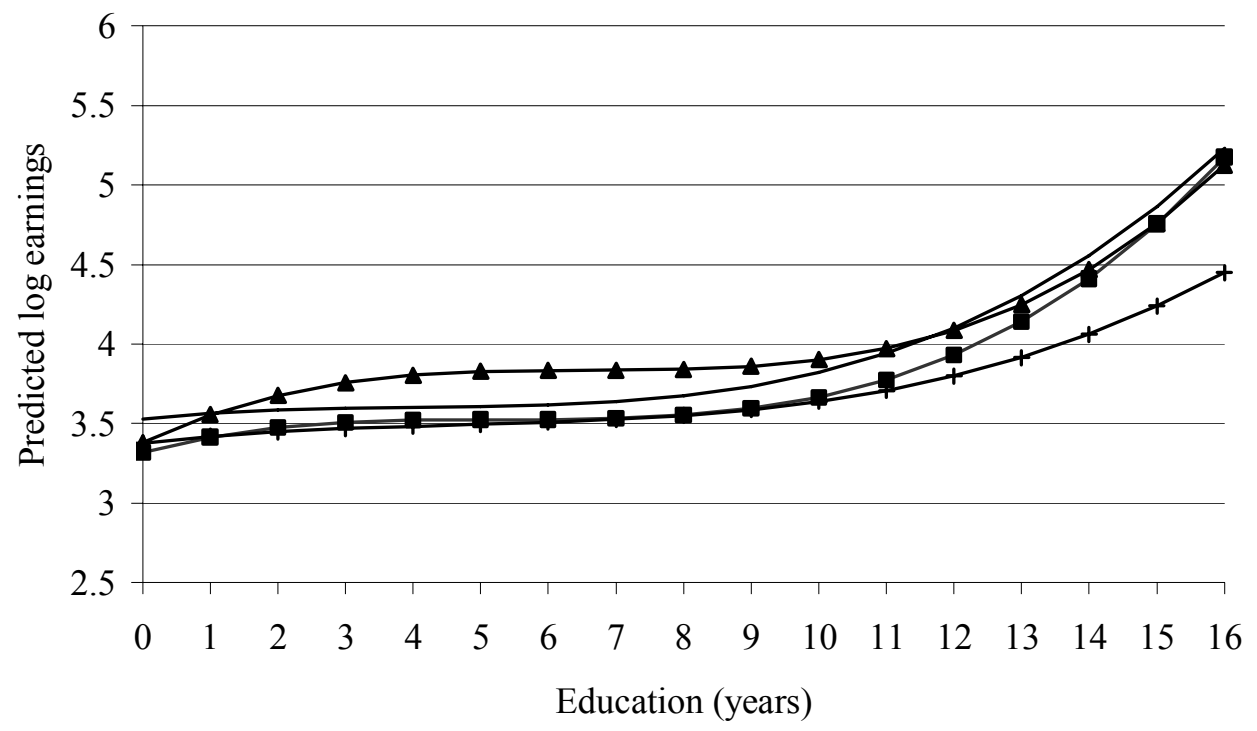

$\rightarrow$ Year $1 \rightarrow$ Year $2 \rightarrow$ Year $3 \longrightarrow$ Year 4

ii) Age group: Old

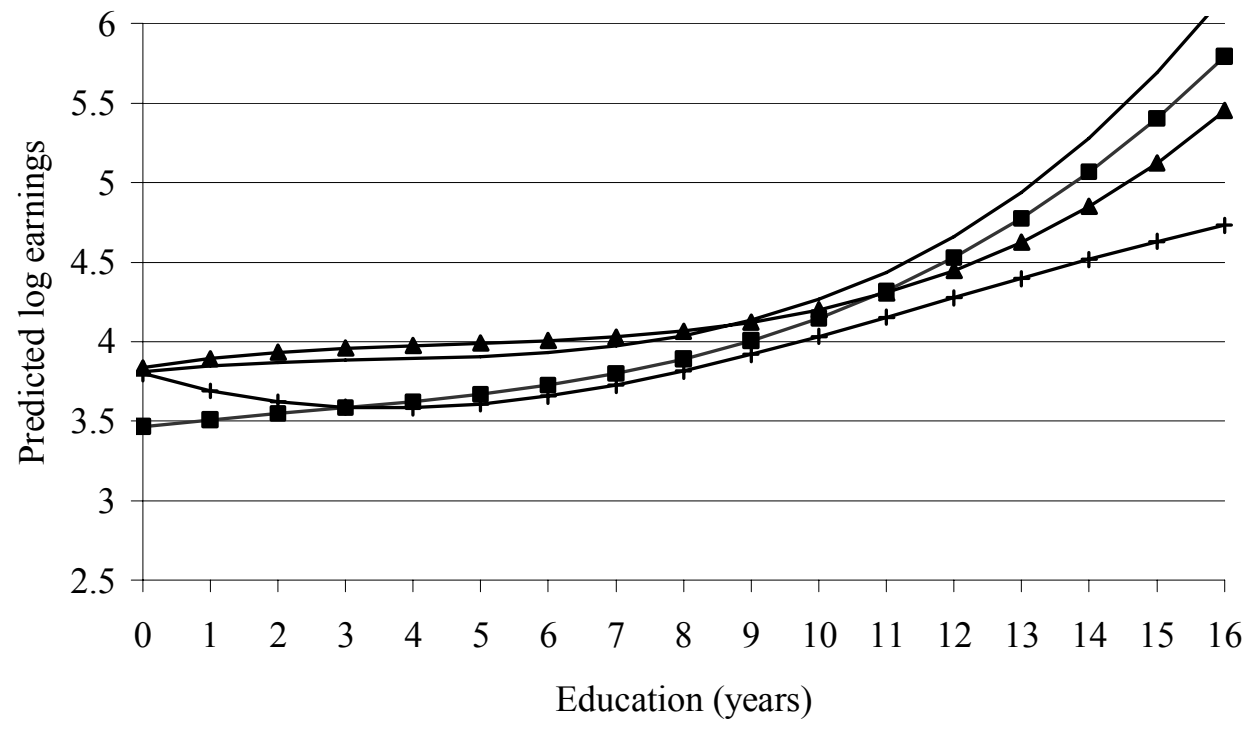

$\rightarrow-$ Year $1 \rightarrow$ Year $2 \rightarrow$ Year $3 \longrightarrow$ Year 4

Note: Year 1 = 1993; Year 2 = 1994; Year 3 = 1995; Year 4 = 2000. 
FiguRE 4B

EARnings and Education, Polynomial Specification: Tanzania

i) Age group: Young

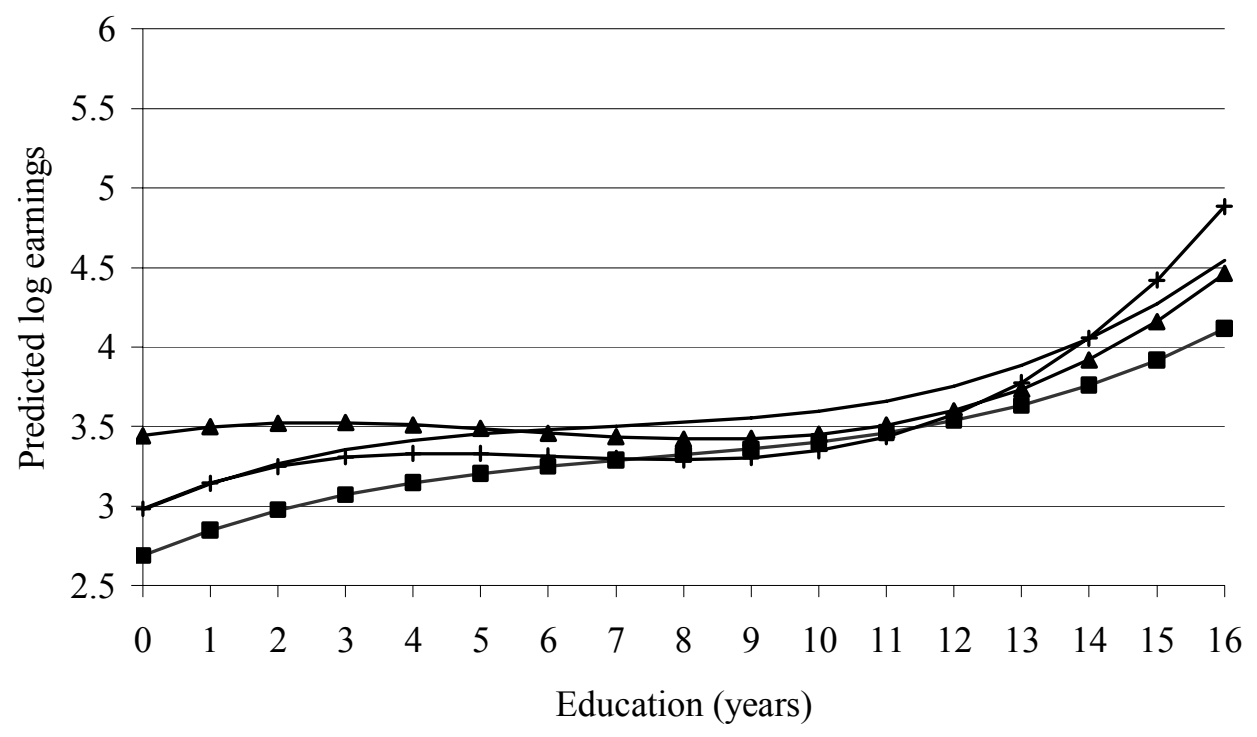

$\rightarrow$ Year $1 \rightarrow$ Year $2 \rightarrow$ Year $3 \longrightarrow$ Year 4

ii) Age group: Old

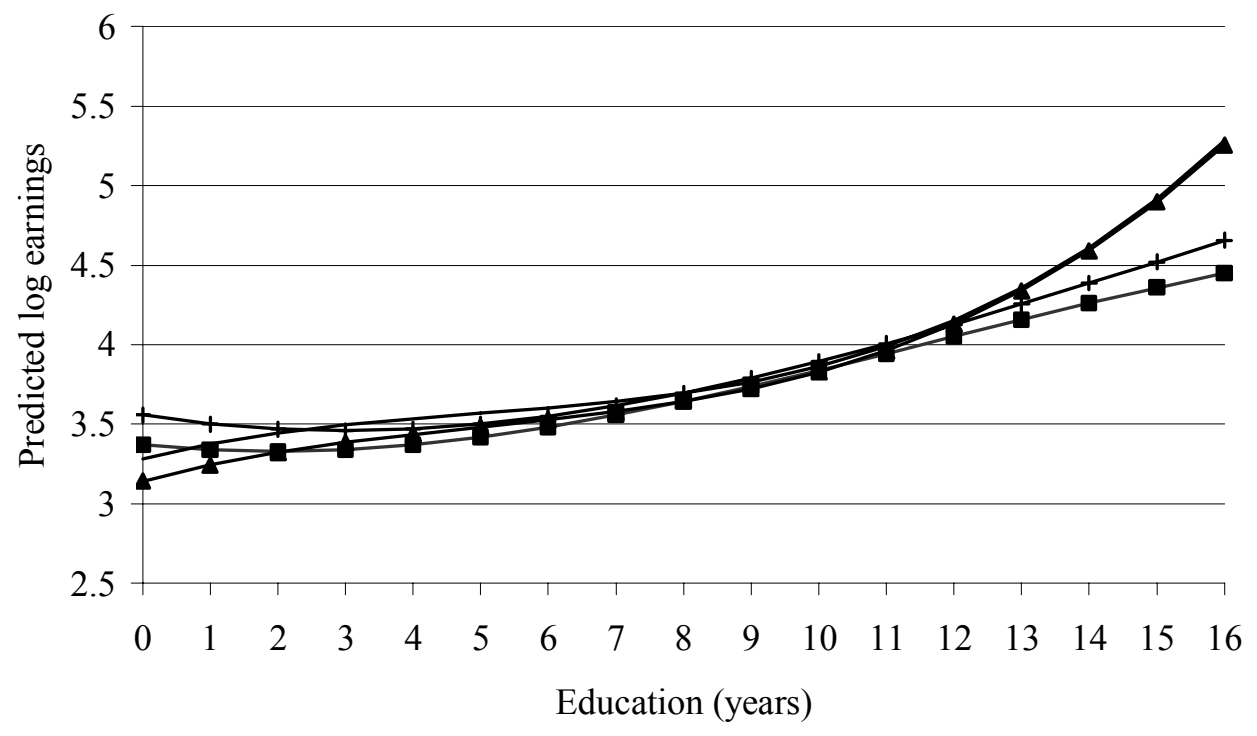

$\rightarrow$ Year $1 \multimap$ Year $2 \rightarrow$ Year $3-$ Year 4

Note: Year 1 = 1993; Year 2 = 1994; Year 3 = 1999; Year 4 = 2001. 